SVERIGES RIKSBANK

WORKING PAPER SERIES

209

Sticky Information vs.

Sticky Prices: A Horse Race in a DSGE Framework

Mathias Trabandt

JUNE 2007 
WORKING PAPERS ARE OBTAINABLE FROM

Sveriges Riksbank •Information Riksbank • SE-103 37 Stockholm Fax international: +4687870526

Telephone international: +4687870100

E-mail: info@riksbank.se

The Working Paper series presents reports on matters in the sphere of activities of the Riksbank that are considered to be of interest to a wider public.

The papers are to be regarded as reports on ongoing studies and the authors will be pleased to receive comments.

The views expressed in Working Papers are solely the responsibility of the authors and should not to be interpreted as reflecting the views of the Executive Board of Sveriges Riksbank. 


\title{
Sticky Information vs. Sticky Prices: A Horse Race in a DSGE Framework*
}

\author{
Mathias Trabandt ${ }^{\dagger}$ \\ Sveriges Riksbank Working Paper Series
}

No. 209

June 2007

\begin{abstract}
How can we explain the observed behavior of aggregate inflation in response to e.g. monetary policy changes? Mankiw and Reis (2002) have proposed sticky information as an alternative to Calvo sticky prices in order to model the conventional view that $i$ ) inflation reacts with delay and gradually to a monetary policy shock, ii) announced and credible disinflations are contractionary and iii) inflation accelerates with vigorous economic activity. I use a fully-fledged DSGE model with sticky information and compare it to Calvo sticky prices, allowing also for dynamic inflation indexation as in Christiano, Eichenbaum, and Evans (2005). I find that sticky information and sticky prices with dynamic inflation indexation do equally well in my DSGE model in delivering the conventional view.
\end{abstract}

Key words: sticky information, sticky prices, inflation indexation, DSGE

JEL Classification: E0, E3

${ }^{*}$ I am thankful to Harald Uhlig for invaluable advice and encouragement. Further, I thank Michael Burda, Ralf Brüggemann, Jordi Gali, David Lopez-Salido, Benjamin Keen, Timothy Kehoe, Oleg Korenok, Omar Licandro, Bartosz Mackowiak, Morten Ravn, Gregory Mankiw, Ricardo Reis, Almuth Scholl, Frank Smets, Fabio Schiantarelli, Carsten Trenkler, Carl Walsh, Michael Woodford as well as seminar participants at Humboldt University Berlin, Deutsche Bundesbank, ECB, EUI in Florence, EEA meeting in Vienna, Kiel Institute of World Economics, Workshop for Dynamic Macroeconomics in Vigo, SED meeting in Florence and at the Verein für Socialpolitik Meeting in Dresden for very helpful comments. This research was supported by the DFG through the SFB 373 and SFB 649 and by the RTN network MAPMU (contract HPRN-CT-2002-00237). I am grateful to the EUI in Florence for its hospitality during a research stay where part of this paper was written. The views expressed in this paper are solely the responsibility of the authors and should not be interpreted as reflecting the views of Sveriges Riksbank.

${ }^{\dagger}$ Sveriges Riksbank, Research Division, Brunkebergstorg 11, SE-103 37 Stockholm, Tel. +46-(0)-8-7870438, email: mathias.trabandt@riksbank.se. 


\section{Introduction}

How can we explain the observed behavior of aggregate inflation in response to e.g. monetary policy changes? An important determinant for the behavior of aggregate inflation is the underlying price setting mechanism of firms. Are firms able to set prices optimally in every instance of time? The recent literature believes they are not, see e.g. Walsh (2003) and Woodford (2003). Rather, the decisions of firms which prices to set on the markets are affected by frictions such as costs of acquiring, absorbing and processing information or by inabilities of changing prices. What are the consequences of these frictions for the behavior of aggregate inflation in response to e.g. changes in monetary policy? In particular, this paper focuses on the question whether aggregate inflation behavior can be better explained by the price setting behavior of firms that face imperfect information or by firms that face inabilities of resetting prices. A substantial part of the literature attempts to explain the behavior of aggregate inflation in response to monetary policy changes by short-run nominal price rigidities. A leading framework has been provided by Calvo (1983) and used e.g. by Woodford (1996), Yun (1996), Goodfriend and King (1997), Clarida, Gali, and Gertler (1999), Gali (2003) and Woodford (2003). Mankiw and Reis (2002) have proposed random information arrival and slow information diffusion as an alternative paradigm. They argue that models based on sticky information can more easily reproduce the following conventional views:

1. Inflation inertia: inflation reacts with delay and gradually to a shock in monetary policy (see e.g. Christiano, Eichenbaum, and Evans (2005)).

2. Announced and credible disinflations are contractionary (see Ball (1994)).

3. Acceleration phenomenon: the change in inflation is positively correlated with output (see e.g. Abel and Bernanke (1998)).

However, Mankiw and Reis (2002) draw their conclusion based on a highly stylized partial equilibrium model. Is that an appropriate description of an economy? In the 
presence of information or price rigidities, output is typically demand determined. Mankiw and Reis (2002) assume, however, that demand is exogenously given. The question that arises is: what happens to their results if demand is endogenously determined in an economy? Put differently, how important are general equilibrium forces such as intertemporally optimized goods and money demand for the price setting behavior of firms and hence for aggregate inflation in an economy? One objective of the present paper is to answer these questions. To that end, I use a fully-fledged dynamic stochastic general equilibrium (DSGE) framework similar to Woodford (2003). I believe that this is an interesting framework since it represents a standard small-scale workhorse DSGE model for the analysis of e.g. monetary policy. I integrate sticky information into this DSGE framework and compare the results to those, when Calvo sticky prices are assumed instead. This modifies the comparison envisioned by Mankiw and Reis (2002) in two important dimensions. First, by employing a DSGE model, aggregate demand now arises from an intertemporal household maximization problem rather than from an exogenously assumed static demand curve as in Mankiw and Reis (2002). Second, as a variation to standard Calvo sticky prices, I allow also for dynamic inflation indexation in the Calvo sticky price model as it has been proposed in the recent literature, see Christiano, Eichenbaum, and Evans (2005) and Smets and Wouters (2003).

Regarding the sticky information model my results confirm the finding by Mankiw and Reis (2002): all three effects listed above can be replicated in my baseline DSGE model as well. A sensitivity analysis reveals that my result is robust with respect to parameter variations. However, general equilibrium features such as forward looking households and interest elastic money demand are nevertheless important. In particular, I find that e.g. inflation and the output gap in the sticky information model react already in the announcement periods to an announced disinflation due to consumption smoothing households and interest elastic money demand in general equilibrium. ${ }^{1}$ Further, we show that a Calvo sticky price model without inflation in-

\footnotetext{
${ }^{1}$ Mankiw and Reis (2002) find in their partial equilibrium model that for sticky information there is absolutely no reaction of inflation in response to the announcement and variables react only when policy is implemented.
} 
dexation can already match the conventional view that announced and credible disinflations are contractionary due to the existence of interest elastic money demand in general equilibrium in my baseline DSGE model. ${ }^{2}$ This result appears also to be robust within my DSGE framework. Finally, we allow for dynamic inflation indexation in the Calvo sticky price model and show that in my baseline DSGE model this works just as well as sticky information à la Mankiw and Reis (2002) in delivering all three effects. Again, result appears also to be robust to variations in key structural parameters of the model.

I conclude that sticky information as in Mankiw and Reis (2002) as well as sticky prices with dynamic inflation indexation as in Christiano, Eichenbaum, and Evans (2005) are perfectly capable of replicating the conventional wisdom with respect to inflation inertia, announced disinflations and the acceleration phenomenon in the DSGE model used in this paper. However, the source of e.g. inflation inertia in both models is different. In the sticky information model, inflation inertia arise due to slow information diffusion. In the sticky price model with dynamic inflation indexation, inflation inertia is hard-wired by assuming that non-optimizing firms index prices to past inflation. Hence, these firms use a very limited outdated information set. Thus, one might want to view information stickiness as providing a micro foundation for the particular choice of dynamic inflation indexation in Calvo sticky price models. Although both models perform equally well with respect to my measures, I believe that sticky information might be better suited to explain the underlying micro behavior of price setting firms.

The paper is organized as follows. Section two lays out the DSGE model. Results are discussed in section three. Section four discusses the related literature and finally section five concludes.

\footnotetext{
${ }^{2}$ Due to their partial equilibrium model, Mankiw and Reis (2002) find that announced and credible disinflations are expansionary in the standard Calvo sticky price model.
} 


\section{The DSGE Model}

In the following section I lay out a fully-fledged DSGE model similar to Woodford (2003) with intertemporally optimizing households, a government and either sticky information firms or Calvo sticky price firms.

\subsection{Households}

The representative agent maximizes the discounted sum of life-time utility,

$$
\max _{C_{t}, M_{t}, N_{t}(i), D_{t+1}} E_{0} \sum_{t=0}^{\infty} \beta^{t}\left[\frac{C_{t}^{1-\sigma}-1}{1-\sigma}+\frac{\chi}{1-v}\left[\left(\frac{M_{t}}{P_{t}}\right)^{1-v}-1\right]-\delta \int_{0}^{1} \frac{N_{t}(i)^{1+\phi}}{1+\phi} d i\right]
$$

subject to

$$
\begin{aligned}
& \int_{0}^{1} P_{t}(i) C_{t}(i) d i+M_{t}^{d}+E_{t}\left[Q_{t, t+1} D_{t+1}\right] \leq \\
& \int_{0}^{1} W_{t}(i) N_{t}(i) d i-T_{t}+M_{t-1}^{d}+D_{t}+\int_{0}^{1} \Pi_{t}(i) d i
\end{aligned}
$$

where $C_{t}$ denotes a composite consumption index which is defined as $C_{t} \equiv\left[\int_{0}^{1} C_{t}(i)^{\frac{\theta-1}{\theta}} d i\right]^{\frac{\theta}{\theta-1}}$. This in turn implies the following for the aggregate price level: $P_{t} \equiv\left[\int_{0}^{1} P_{t}(i)^{1-\theta} d i\right]^{\frac{1}{1-\theta}} \cdot M_{t}$ denotes nominal money. I assume that each categorized good $i$ is produced by using specialized labor $N_{t}(i)$ which is supplied by the representative household. $W_{t}(i)$ is the wage that is payed from firm $i$ to the household. As in Woodford (2003), the assumption of specific labor markets generates strategic complementarities in firm's pricing decisions. $D_{t+1}$ is a nominally denominated state contingent private bond that pays $D_{t+1}$ in period $t+1$. $Q_{t, t+k}$ is the stochastic discount factor from period $t$ to $t+k$ for nominal claims. $T_{t}$ denotes a lump-sum tax of the government. Finally, the household receives profits $\Pi_{t}(i)$ of the 
firms. The household is endowed with one unit of time (normalized) to be allocated between hours of work and leisure. Information is complete for the agent.

\subsection{Government}

The government issues nominal money $M_{t}$ and nominal bonds $B_{t}$ and collects lump sum taxes $T_{t}$ to finance its expenditures $G_{t}$,

$$
P_{t} G_{t}=T_{t}+B_{t}-R_{t-1} B_{t-1}+S_{t}
$$

where $S_{t}=M_{t-1}\left(\xi_{t}-1\right) . P_{t}$ is the aggregate price level, $R_{t-1}$ denotes the nominal interest rate from period $t-1$ to period $t$ and $\xi_{t}=\frac{M_{t}}{M_{t-1}}$ is nominal money growth. I assume $\xi_{t}$ and $G_{t}$ to follow exogenous $\operatorname{AR}(1)$ processes.

\subsection{Firms}

Following Woodford (2003), I assume a continuum of firms $i \in[0,1]$ in monopolistic competition each producing a differentiated good according to $Y_{t}(i)=Z_{t} N_{t}^{\alpha}(i)$. $Y_{t}(i)$ denotes the differentiated good and $N_{t}(i)$ is specific labor input of firm $i$. $Z_{t}$ denotes technology which is assumed to follow an exogenous $\mathrm{AR}(1)$ process. With price $P_{t}(i)$ for firm $i$ and $P_{t}$ as the aggregate price level, firm demand is given by $Y^{d}\left(P_{t}(i) ; P_{t}, C_{t}, G_{t}\right)=Y_{t}^{d}(i)=\left(\frac{P_{t}(i)}{P_{t}}\right)^{-\theta}\left(C_{t}+G_{t}\right)$. As in Woodford (2003), I assume that firms are wage-takers. ${ }^{3}$ Finally, labor input for firm $i$ is given by $N\left(P_{t}(i) ; Y_{t}^{d}, Z_{t}\right)=N_{t}(i)=\left(\frac{Y_{t}^{d}(i)}{Z_{t}}\right)^{\frac{1}{\alpha}}$. Now, I consider four different variants for the price setting behavior by firms.

\footnotetext{
${ }^{3}$ Woodford (2003, ch. 3, p. 148) points out: "Here I assume that the producer is a wagetaker, even though I have supposed that the supplier of each differentiated good uses a different type of labor with its own market. But an assumption of differentiated labor inputs need not imply that each producer is a monopsonist in its labor market. The only assumption that is important for the subsequent results is that producers that change their prices at different times also hire labor inputs from distinct markets. I might, for example, assume a double continuum of differentiated goods, indexed by $(I, j)$, with an elasticity of substitution of $\theta$ between any two goods, as previously. It might then be assumed that all goods with the same index I (goods in the same "industry") change their prices at the same time (and so always charge the same price), and are also all produced using the same type of labor (type I labor). The degree of market power of each producer in its product market would then be as assumed here, but the fact that a continuum of producers all bid for type I labor would eliminate any market power in their labor market...".
} 


\section{Flexible Price - Full Information Firms}

In the absence of any nominal and informational frictions firms choose prices each period to maximize profits,

$$
\max _{P_{t}(i)} P_{t}(i) Y_{t}^{d}(i)-W_{t}(i)\left(\frac{Y_{t}^{d}(i)}{Z_{t}}\right)^{\frac{1}{\alpha}}
$$

subject to

$$
Y_{t}^{d}(i)=\left(\frac{P_{t}(i)}{P_{t}}\right)^{-\theta}\left(C_{t}+G_{t}\right)
$$

I denote $P_{t}^{*}(i)$ as a solution of the above maximization problem.

\section{Sticky Information Firms}

Following Mankiw and Reis (2002), firms obtain new information with probability $1-\lambda_{1}$. These firms are able to find the profit maximizing price $P_{t}^{*}(i)$. With probability $\lambda_{1}$ firms do not obtain new information. These firms use the information set they updated $k$ periods ago to compute optimal prices. Formally, these firms solve

$$
\max _{P_{t+j}(i)} \sum_{j=0}^{\infty} \lambda_{1}^{j} E_{t-k}\left[Q_{t, t+j}\left(P_{t+j}(i) Y_{t+j}^{d}(i)-W_{t+j}(i)\left(\frac{Y_{t+j}^{d}(i)}{Z_{t+j}}\right)^{\frac{1}{\alpha}}\right)\right]
$$

subject to

$$
Y_{t+j}^{d}(i)=\left(\frac{P_{t+j}(i)}{P_{t+j}}\right)^{-\theta}\left(C_{t+j}+G_{t+j}\right) .
$$

The optimal log-linear pricing rule for sticky information firms can be written as follows ${ }^{4}$

$$
\hat{p}_{t+j}(i)=E_{t-k}\left[\hat{w}_{t+j}(i)-\frac{1}{\alpha} \hat{z}_{t+j}+\left(\frac{1}{\alpha}-1\right) \hat{y}_{t+j}^{d}(i)\right] \quad \forall j \geq 0 .
$$

Note that the right hand side of this equation is the conditional expectation of the $\log$-linearized version of $P_{t+j}^{*}(i)$ which is the profit maximizing price in the absence of any nominal and informational frictions. After some tedious manipulations I

\footnotetext{
${ }^{4}$ Hat-variables denote percentage deviations from steady state.
} 
arrive at $\hat{p}_{t+j}(i)=E_{t-k}\left[\hat{p}_{t+j}+\zeta \hat{x}_{t+j}\right]$ for $\forall j \geq 0$ with $\zeta=\frac{\omega+\sigma \sigma_{c}^{-1}}{1+\theta \omega}$ and $\omega=\frac{\phi}{\alpha}+\frac{1}{\alpha}-1$. $\hat{x}_{t}$ denotes the output gap, defined as the difference between the distorted and the flexible price - full information output. Thus, in period $t$, a firm that updated its information set $k$ periods ago sets the adjustment price

$$
\hat{p}_{k, t}^{a d j}(i)=E_{t-k}\left[\hat{p}_{t}+\zeta \hat{x}_{t}\right]
$$

Finally, the aggregate price level is the average of all adjustment prices in $t$

$$
\hat{p}_{t}=\left(1-\lambda_{1}\right) \sum_{k=0}^{\infty} \lambda_{1}^{k} \hat{p}_{k, t}^{a d j}(i)
$$

\section{Sticky Price Firms}

According to Calvo (1983), sticky price firms can set their profit maximizing price $\tilde{P}_{t}(i)$ with probability $1-\lambda_{2}$. With probability $\lambda_{2}$ firms cannot set their optimal price. These firms have to keep last period's price and set $P_{t}(i)=P_{t-1}(i)$. Formally, these firms solve

$$
\max _{P_{t}(i)} \sum_{j=0}^{\infty} \lambda_{2}^{j} E_{t}\left[Q_{t, t+j}\left(P_{t}(i) Y_{t+j}^{d}(i)-W_{t+j}(i)\left(\frac{Y_{t+j}^{d}(i)}{Z_{t+j}}\right)^{\frac{1}{\alpha}}\right)\right]
$$

subject to

$$
Y_{t+j}^{d}(i)=\left(\frac{P_{t}(i)}{P_{t+j}}\right)^{-\theta}\left(C_{t+j}+G_{t+j}\right)
$$

The aggregate price level in case of Calvo sticky prices can be written as

$$
P_{t}=\left[\left(1-\lambda_{2}\right) \tilde{P}_{t}^{1-\theta}+\lambda_{2} P_{t-1}^{1-\theta}\right]^{\frac{1}{1-\theta}}
$$

with $\tilde{P}_{t}$ as the solution to the above maximization problem. 


\section{Sticky Price Firms With Dynamic Inflation Indexation}

Empirical studies, see e.g. Gali and Gertler (1999) and Gali, Gertler, and LopezSalido (2005), suggest that lagged inflation is an important determinant for the New Keynesian Phillips curve. In order to account for this, Christiano, Eichenbaum, and Evans (2005) employ dynamic inflation indexation as a modification to the standard Calvo sticky price approach. With probability $1-\lambda_{3}$ firms can set their optimal price $\tilde{P}_{t}^{*}(i)$. With probability $\lambda_{3}$ firms cannot set their optimal price. Following Christiano, Eichenbaum, and Evans (2005), these firms set the price $P_{t}(i)=\Pi_{t-1} P_{t-1}(i)$. The non-optimizers apply a rule of thumb by updating last period's price $P_{t-1}(i)$ with yesterday's gross inflation rate $\Pi_{t-1} \cdot{ }^{5}$ Formally, these firms solve

$$
\max _{P_{t}(i)} \sum_{j=0}^{\infty} \lambda_{3}^{j} E_{t}\left[Q_{t, t+j}\left(U_{t, j} P_{t}(i) \breve{Y}_{t+j}^{d}(i)-W_{t+j}(i)\left(\frac{\breve{Y}_{t+j}^{d}(i)}{Z_{t+j}}\right)^{\frac{1}{\alpha}}\right)\right]
$$

subject to

$$
\breve{Y}_{t+j}^{d}(i)=\left(\frac{U_{t, j} P_{t}(i)}{P_{t+j}}\right)^{-\theta}\left(C_{t+j}+G_{t+j}\right)
$$

with $U_{t, j}=\Pi_{t} \times \Pi_{t+1} \times \ldots \times \Pi_{t+j-1}$ for $j \geq 1$ and $U_{t, j}=1$ for $j=0$. The aggregate price level in the presence of sticky prices and dynamic inflation indexation can be written as

$$
P_{t}=\left[\left(1-\lambda_{3}\right)\left(\tilde{P}_{t}^{*}\right)^{1-\theta}+\lambda_{3}\left(\Pi_{t-1} P_{t-1}\right)^{1-\theta}\right]^{\frac{1}{1-\theta}}
$$

with $\tilde{P}_{t}^{*}$ as the solution to the above dynamic programming problem.

\footnotetext{
${ }^{5}$ There are, of course, alternative approaches to indexation in the literature. Yun (1996) assumes indexation to steady state inflation, e.g. $P_{t}(i)=\bar{\Pi} P_{t-1}(i)$. Although this leads to a vertical long-run Phillips curve the dynamics are still entirely forward looking and hence inflation is not inertial. Smets and Wouters (2003) and Giannoni and Woodford (2003) assume partial dynamic inflation indexation, e.g. $P_{t}(i)=\Pi_{t-1}^{\gamma} P_{t-1}(i)$ with $0 \leq \gamma \leq 1$. Smets and Wouters (2003) estimate $\gamma$ to be roughly 0.65 for European data. Gali, Gertler, and Lopez-Salido (2001) estimate $\gamma$ to be equal to 0.6 for European and US data. By contrast, Giannoni and Woodford (2003) find that $\gamma=1$ delivers the best fitting value for US data and thereby confirm Christiano, Eichenbaum, and Evans (2005) choice of full dynamic indexation. To that end, I am most interested in the consequences of full dynamic indexation for the dynamics of inflation. Therefore, my results can be interpreted as representing an upper bound compared to cases of partial dynamic inflation indexation.
} 


\subsection{Equilibrium}

In equilibrium all markets clear. I log-linearize my equilibrium conditions. Hatvariables denote percentage deviations from steady state. The DSGE framework can be characterized by the following set of equations: an intertemporal IS equation, a real money demand equation, a real money supply equation, an equation for the flexible price - full information real interest rate and the equations for the exogenous $\mathrm{AR}(1)$ processes for technology, money growth and government expenditures. See appendix A.1 for a formal description.

Into this DSGE framework, I throw in either one of the following three Phillips curves:

1. Under sticky information I derive the so-called Sticky Information Phillips curve $^{6}$

$$
\hat{\pi}_{t}=\frac{1-\lambda_{1}}{\lambda_{1}} \zeta \hat{x}_{t}+\left(1-\lambda_{1}\right) \sum_{k=0}^{\infty} \lambda_{1}^{k} E_{t-k-1}\left[\hat{\pi}_{t}+\zeta \triangle \hat{x}_{t}\right]
$$

with $\zeta=\frac{\omega+\sigma S_{c}^{-1}}{1+\theta \omega}$ and $\omega=\frac{\phi}{\alpha}+\frac{1}{\alpha}-1$ as before. $\hat{\pi}_{t}$ is the gross inflation rate and $\hat{x}_{t}$ denotes the output gap, defined as the difference between the distorted and the flexible price - full information output. ${ }^{7}$ Note that for $\zeta<1$ firms pricing decisions are strategic complements which allows for potential inflation inertia as discussed extensively in Woodford (2003).

\footnotetext{
${ }^{6}$ Similar to the derivation steps described in Mankiw and Reis (2002), I substitute equation (7) into equation (8). After taking first differences and some tedious manipulations, I arrive at equation (15).

${ }^{7}$ In order to derive the Sticky Information Phillips curve I needed three assumptions: i) firms use outdated information and obtain new information infrequently, ii) firms set prices rather than quantities and iii) the information arrival follows a Poisson process. Reis (2006) develops a model where firms just face costs of acquiring, absorbing or processing information and shows that this inattentiveness model provides mirco-foundations for the three assumptions listed above.
} 
2. Under standard Calvo sticky prices I derive the so-called New Keynesian Phillips curve $^{8}$

$$
\hat{\pi}_{t}=\beta E_{t}\left[\hat{\pi}_{t+1}\right]+\kappa \hat{x}_{t}
$$

with $\kappa=\frac{\left(1-\lambda_{2}\right)\left(1-\lambda_{2} \beta\right)}{\lambda_{2}} \zeta$.

3. Finally, under Calvo sticky prices with indexation I arrive at the so-called New Keynesian Phillips curve with dynamic inflation indexation or hybrid New Keynesian Phillips curve ${ }^{9}$

$$
\hat{\pi}_{t}=\frac{1}{1+\beta} \hat{\pi}_{t-1}+\frac{\beta}{1+\beta} E_{t}\left[\hat{\pi}_{t+1}\right]+\frac{\kappa^{\prime}}{1+\beta} \hat{x}_{t}
$$

with $\kappa^{\prime}=\frac{\left(1-\lambda_{3}\right)\left(1-\lambda_{3} \beta\right)}{\lambda_{3}} \zeta$.

According to the Sticky Information Phillips curve, inflation is determined by current economic activity and by past expectations about current inflation and current economic activity. If new information arrives only some firms will be informed and change prices accordingly whereas most firms still set prices based on outdated information. As time elapses the fraction of firms that set prices based on new information increases and therefore, it is likely that inflation behaves inertial in response to new information.

By contrast, in the New Keynesian Phillips curve inflation is determined by current expectations about future inflation and by current economic activity. Thus, the New Keynesian Phillips curve is entirely forward looking and therefore inflation will immediately jump on impact rather than reacting with delay in response to new information

\footnotetext{
${ }^{8}$ To do so, I combine the log-linearized solution of equation (9) with the log-linearized version of equation (11). After some tedious manipulations, I arrive at equation (16).

${ }^{9}$ Similar to the derivations for the Calvo sticky price model, I combine the log-linearized solution of (12) with the log-linearized version of equation (14) and arrive at equation (17) after some further tedious manipulations.
} 
The New Keynesian Phillips curve with dynamic indexation shows that inflation is determined by past inflation, by current expectations about future inflation and by current economic activity. It is the backward looking inflation component due to dynamic inflation indexation which makes it likely that inflation behaves inertial in response to new information.

\subsection{Microfoundation for Inflation Indexation}

Based on the analysis of the previous section, it is the backward looking rule of thumb behavior of non-optimizing Calvo sticky price firms that potentially produces the desired inertial reaction of inflation. But which rule of thumb should by applied? Christiano, Eichenbaum, and Evans (2005) assume that last period's inflation is used to update prices of non-optimizing firms. Thus, these firms use inflation information that is outdated by one period. Clearly, one could assume instead that non-optimizers use inflation observed two periods ago to update their prices. It is also conceivable that they could use even older information to update their prices. Hence, the particular choice how old the information regarding inflation is that firms use to update their prices is ad-hoc in the Calvo sticky price model with dynamic inflation indexation.

By contrast, the sticky information model implies that the choice of inflation indexation depends on the particular information sets that are available to heterogenous firms. Some firms may be forced to use past period's information set including e.g. past period's inflation rate, output etc. Other firms may be forced to use even older information sets also including even older e.g inflation rates, output etc. All these firms use their individually outdated information sets to update prices. Due to this, it takes time in the sticky information model until a sufficiently large fraction of firms has received news and changes prices accordingly and thus inflation inertia are likely to occur. By contrast, in the sticky price model with dynamic inflation indexation as in Christiano, Eichenbaum, and Evans (2005), inflation inertia are hard-wired in by 
assuming indexation to past inflation for all non-optimizing firms. Hence, these firms use a very limited outdated information set only.

Put differently, these firms face costs of acquiring, absorbing and processing information about current e.g. inflation and output but have free access to past period's inflation rate and therefore choose to update their prices using this information. From that perspective, one might want to view information stickiness as providing a micro foundation for the particular choice of dynamic inflation indexation in Calvo sticky price models. ${ }^{10}$

However, the present paper aims at a comparison of the consequences of the three existing alternative pricing assumptions and their resulting Phillips curves in a DSGE framework taking the conventional wisdom as a measuring instrument.

\subsection{Parameterization}

In order to analyze the implications of the model, I need to parameterize it. In principle, there are two ways to proceed. First, one could estimate the model and use the estimated parameters to parameterize the model. This however, turns out to be a thorny issue. My models belong to the class of small-scale DSGE models. That is, they contain only a single friction e.g. sticky information or sticky prices. Ever since Christiano, Eichenbaum, and Evans (2005), Smets and Wouters (2003) as well as Mankiw and Reis (2006b) we know that further nominal and real frictions such as sticky wages, habit persistence, capacity and investment adjustment costs, limited participation or sticky information in other markets are necessary to obtain a reasonably good fit of the model to the data and hence reasonable parameter estimates.

\footnotetext{
${ }^{10}$ Recently, Dupor, Kitamura, and Tsuruga (2006) derive a model of dual stickiness. They assume that only a fraction of firms may reset prices and simultaneously receives new information. All remaining firms keep setting prices based on old and outdated information. In a highly stylized economic environment, they show that the dual stickiness model and a sticky price model with dynamic inflation indexation deliver similar, though not identical, responses of inflation after a money growth shock. Hence, they confirm my reasoning that information stickiness may provide a micro foundation for indexation in sticky price models.
} 
Hence, estimating my small-scale DSGE models would probably result in biased results since the data would assign all these frictions to either sticky prices or sticky information. Enriching my model by these additional frictions would certainly be a useful step. However, this would also fog up the key questions raised in this paper. More precisely, each enriched model would potentially assign different weights to various frictions and hence it would be difficult to evaluate how much of the differences between sticky information and sticky prices are due to these additional frictions.

Instead, and in the light of Mankiw and Reis (2002), I evaluate the qualitative ability of the models to deliver the three conventional effects. In other words, the conventional effects itself are of rather qualitative nature and I examine the models ability to reflect them qualitatively. In terms of parameters, I therefore rely on standard values used in the literature and pursue a sensitivity analysis to evaluate the robustness of the qualitative predictions of the models.

Table 1 summarizes the parameterization of my models. Time is taken to be quarters. The subjective discount factor $\beta$ is set to 0.99 . Similar to Woodford (2003), steady state inflation is set to zero, i.e. $\bar{\Pi}=1+\bar{\pi}=1 .{ }^{11}$ The inverse Frisch elasticity of labor supply $\phi$ is set to 1.5. The coefficient of relative risk aversion of consumption $\sigma$ and the elasticity of utility with respect to real money holdings $v$ are set to 2 . Real money demand in my model is given by

$$
\log m_{t}=\frac{1}{v} \log \chi+\frac{\sigma}{v} \log c_{t}-\frac{1}{v} \log \frac{R_{t}-1}{R_{t}} .
$$

Thus, my choice implies a unit consumption elasticity of real money demand $\left(\partial \log m_{t} / \partial \log c_{t}=\sigma / v=1\right)$ which is in line with most empirical evidence on money demand. Further, my choice also implies the following semi interest rate elasticity

\footnotetext{
${ }^{11}$ See Ascari (2004) for an analysis of the effects of positive steady state inflation. In particular, he shows that trend inflation affects the dynamics of inflation and output in the standard Calvo sticky price model. However, as soon as either steady state or dynamic inflation indexation are assumed, the dynamics of the models are not affected by positive steady state inflation.
} 
$\partial \log m_{t} / \partial r_{t}=-\frac{1}{v(\bar{R}-1) \bar{R}}=-49.5 .^{12}$ The labor share $\alpha$ in the production function is assumed to be $\frac{2}{3}$. As in Mankiw and Reis (2002), the degree of information rigidity $\left(\lambda_{1}\right)$ respectively the degree of price stickiness $\left(\lambda_{2}, \lambda_{3}\right)$ is set to 0.75 . Thus, in case of the Calvo sticky price model, firms set optimal prices on average once a year. In the case of the sticky information model, firms obtain new information on average once a year. ${ }^{13}$ I assume a markup over marginal costs of 20 percent i.e. $\frac{\theta}{\theta-1}=1.2$ as in Gali and Monacelli (2005). The steady state consumption to output ratio $s_{c}$ is set to 0.7 , a value that corresponds to the US average for the period from 1960:1 to 2001:4. The $\mathrm{AR}(1)$ process for technology is calibrated to standard values with an autocorrelation of $\rho_{z}=0.95$ and a standard deviation of $\sigma_{z}=0.71$ percent. The AR(1) process for money growth is specified with a persistence parameter of $\rho_{\xi}=0.5$ and a standard deviation of $\sigma_{\xi}=0.8$ percent, similar to Mankiw and Reis (2002) calibration. Finally, as in Backus, Kehoe, and Kydland (1995) the autocorrelation and standard deviation of the $\mathrm{AR}(1)$ process for government expenditures is set to $\rho_{g}=0.95$ and $\sigma_{g}=0.6$ percent. However, in order to access the robustness of my results with respect to my parameter choices I undertake sensitivity checks when discussing the results.

\subsection{Solution Method}

I solve the Calvo sticky price models with and without dynamic inflation indexation using the linear solution algorithm developed in Uhlig (1999). The sticky information model, however, cannot be solved as easily as my other two models. The Sticky Information Phillips curve (see equation (15)) consists of an infinite number of lagged expectations. Therefore, the state space of the sticky information model is infinite.

In their original model, Mankiw and Reis (2002) guessed that the solution for e.g.

\footnotetext{
${ }^{12}$ Note that Chari, Kehoe, and Mcgrattan (2000) estimate $v$ to be approximately 2.5 which is roughly in line with my choice of 2. Empirical evidence in Lucas (2000), Chari, Kehoe, and Mcgrattan (2000), Woodford (2003) and Walsh (2003) (who provides an excellent survey) suggest values for the semi interest rate elasticity ranging from -10 to -100 . Hence, my implied choice of -49.5 is well within that range. Further, I set $\chi=0.05$ which is also in line with many of the references cited above. However, note that $\chi$ is irrelevant for the dynamics of the model. Another parameter that does not affect the dynamics is the disutility of labor $\delta$. However, I set $\delta$ such that the individual chooses to work one third of total time in steady state.

${ }^{13}$ Note that this is in line with empirical studies by Kahn and Zhu (2006), Caroll (2003) and Mankiw, Reis, and Wolfers (2004).
} 
inflation takes a $M A(\infty)$ representation and then solved for the $M A$ coefficients recursively. They were able to do so, because aggregate demand was assumed to be exogenous and static. This solution method, however, does not work as soon as aggregate demand is endogenous and more importantly consists of a dynamic relationship such as the "New IS" curve.

The following question arises: how can one solve or approximate the sticky information model in general equilibrium? I proceed as follows. First, observe that the weight of lagged expectations decreases geometrically in the Sticky Information Phillips curve. That is, expectations that are formed recently have a larger impact on present inflation than similar expectations formed many periods ago. Therefore, it might be that expectations formed very far in the past do not change inflation significantly due to the very low weight that is attached to them. Hence, I ask how many lagged expectations are necessary to approximate the Sticky Information Phillips curve reasonably well. In particular, I rewrite the Sticky Information Phillips curve as

$$
\hat{\pi}_{t}=\frac{1-\lambda_{1}}{\lambda_{1}} \zeta \hat{x}_{t}+\left(1-\lambda_{1}\right) \sum_{k=0}^{N} \lambda_{1}^{k} E_{t-k-1}\left[\hat{\pi}_{t}+\zeta \triangle \hat{x}_{t}\right]
$$

Clearly, as $N \rightarrow \infty$ I obtain the original equation (15). What is the $N$ for which the path of the model variables does not change anymore by a specified tolerance if I add a further lagged expectation, e.g. setting $N=N+1$. I will pursue the following strategy to answer this question:

1. Set $N=0$. That is, use the Sticky Information Phillips curve with only the first lagged expectation $E_{t-1}$ and compute the recursive equilibrium law of motion (RELOM).

2. Set $N=N+1$. Put differently, add the second lagged expectation $E_{t-2}$ to the Sticky Information Phillips curve from above and compute the new RELOM. 
3. Proceed adding lagged expectations by setting $N=N+1$ as long as the coefficients of the RELOM change by more than a specified tolerance.

Figure 1 illustrates the solution algorithm. It shows the impulse responses of inflation to a one percent shock in money growth for a stepwise inclusion of lagged expectations in the Sticky Information Phillips curve. The first plot in the top row shows the response of inflation if the model uses $N=0$, e.g. $\hat{\pi}_{t}=\frac{1-\lambda_{1}}{\lambda_{1}} \zeta \hat{x}_{t}+\left(1-\lambda_{1}\right) E_{t-1}\left[\hat{\pi}_{t}+\right.$ $\left.\zeta \triangle \hat{x}_{t}\right]$. The second plot in the top row shows the response of inflation if the model takes an additional lagged expectation into account by setting $N=N+1=1$ which yields $\hat{\pi}_{t}=\frac{1-\lambda_{1}}{\lambda_{1}} \zeta \hat{x}_{t}+\left(1-\lambda_{1}\right) E_{t-1}\left[\hat{\pi}_{t}+\zeta \triangle \hat{x}_{t}\right]+\left(1-\lambda_{1}\right) \lambda_{1} E_{t-2}\left[\hat{\pi}_{t}+\zeta \triangle \hat{x}_{t}\right]$. Thus, the last plot in the bottom row shows the response of inflation if the sticky information model uses $N=11$ which delivers $\hat{\pi}_{t}=\frac{1-\lambda_{1}}{\lambda_{1}} \zeta \hat{x}_{t}+\left(1-\lambda_{1}\right) \sum_{k=0}^{11} \lambda_{1}^{k} E_{t-k-1}\left[\hat{\pi}_{t}+\right.$ $\left.\zeta \triangle \hat{x}_{t}\right]$. Obviously, figure 1 illustrates that the shape of the response of inflation converges to a smooth hump-shaped pattern as $N$ becomes larger and larger. As an approximation I look for that $N$ where the recursive law of motion for all model variables does not change by more than a specified tolerance/critical value when setting $N=N+1$.

Technically, I apply the QZ-decomposition to obtain the recursive law of motion. Following the notation in Uhlig (1999), the model coefficient matrices $\Delta$ and $\Xi$ can be decomposed into unitary matrices $Y$ and $Z$ and uppertriangular matrices $\Sigma$ and $\Phi$ such that $Y^{\prime} \Sigma Z=\Delta$ and $Y^{\prime} \Phi Z=\Xi$. The recursive law of motion coefficient matrix $P$ which is needed to solve for the other recursive law of motion coefficient matrices, can be obtained by $P=-Z_{21}^{-1} Z_{22}$ where $Z_{21}$ and $Z_{22}$ are partitions of matrix $Z$, defined as in Uhlig (1999). $P, Z_{21}$ and $Z_{22}$ increase in their dimensions as $N$ - the number of included lagged expectations - increases. Additionally $P$ and $Z_{22}$ are singular. Therefore, to check for convergence of the recursive law of motion I look for that $N$ when the determinant of $Z_{21}^{-1}$ does not change by more than a critical value compared to setting $N=N+1$. 
For my problem I choose the tolerance/critical value to be 1e-25 units. This algorithm appears to be robust. I achieve convergence of the recursive equilibrium law of motion after including the 20th lagged expectation, i.e. by setting $N=19$. This result is also intuitively reasonable. As mentioned earlier, the Sticky Information Phillips curve can be interpreted as a geometric sum of past expectations with weights $(1-$ $\lambda) \lambda^{k}$. For my parametrization these weights cumulate to around 99.5 percent after including the 20th lagged expectation. ${ }^{14}$

As a remark, it should be mentioned that one could derive a Sticky Information Phillips curve with a finite number of lagged expectations. I decide not to follow this strategy since it departs too much from Mankiw and Reis (2002) original specification of the Sticky Information Phillips curve. Instead, I developed a fairly accurate algorithm to approximate the originally infinite geometric sum of lagged expectations of the Sticky Information Phillips curve with a finite number of lagged expectations.

Hence, as a further contribution to the literature, I show that a standard linear solution algorithm as e.g. Uhlig (1999) can be used to solve models with lagged expectations like Mankiw and Reis (2002) sticky information model.

\footnotetext{
${ }^{14}$ Recently, Mankiw and Reis (2006b) propose an alternative solution method. They guess that the solution of e.g. the price level can be represented as a $M A(\infty)$ process. They show that the undetermined coefficients of the $M A$ process solve an infinite dimensional second order difference equation with boundary conditions. Mankiw and Reis (2006b) approximate this infinite dimensional difference equation with a finite system of linear equations and a terminal condition. In other words, they approximate the $M A(\infty)$ representation of the solution with a $M A(n)$ representation and choose a sufficiently large $n$. The authors report that for $n=1000$ their algorithm takes approximately 5 seconds to solve for the process of the price level. By contrast, my algorithm approximates directly the number of relevant states, i.e. lagged expectations. It takes approximately three minutes on an up-to-date unix machine to solve the model with $N=19$. However, Mankiw and Reis (2006b) algorithm appears to be constructed for the particular model they wish to solve and adaption to other models seems to involve tedious manual algebraic manipulations. By contrast, my algorithm employs a ready-to-use linear solution algorithm such as Uhlig (1999). In a recent paper, Wang and Wen (2006) propose a solution algorithm for linear difference systems with a finite number of lagged expectations. Thus, the nature of approximation - similar to my algorithm - is that only a finite number of lagged expectations of the Sticky Information Phillips curve are considered. However, the algorithm as such differs from ours. Their key idea is to convert lagged expectations into $n$-step ahead prediction errors which in turn can be represented as a finite $M A(n)$ process. Wang and Wen (2006) convert the finite $M A$ representation into a standard linear difference system. They claim that a $M A(20)$ process delivers very precise results and thereby include 20 lags of the Sticky Information Phillips curve. Note that my solution method arrives at the same conclusion. Unfortunately, Wang and Wen (2006) do not report how fast their algorithm is in terms of CPU time.
} 


\section{Results}

In this section I discuss the results by examining the models ability to deliver the three conventional views stated in the introduction.

\subsection{Inflation Inertia}

First, I analyze the models capability to generate inertial responses of inflation. I focus on the delayed and gradual response of inflation after a monetary policy shock. In addition, I briefly discuss the effects of technology and government expenditure shocks.

\subsubsection{Monetary Policy Shock}

Figure 2 plots the responses of inflation, the output gap, the nominal interest rate and hours worked to a one percent money growth shock for all three models using the baseline parameterization. The sticky information model delivers a hump-shaped pattern of inflation with a maximum impact around the 7th quarter. In period zero when the money growth shock occurs, only the fraction of firms that updated their information in period zero adjust their prices. All other firms remain inattentive and keep setting prices based on outdated information. As time passes by, more and more firms update their information sets and hence change prices in response to the money growth shock. Interestingly, in Mankiw and Reis (2002) original partial equilibrium model, inflation peaks at the 8th quarter after the money growth shock. To that end, my result indicates that sticky information in my DSGE model is able to deliver similar inflation inertia as in Mankiw and Reis (2002). Put differently, I observe a pronounced hump-shape of inflation which indicates that the Sticky Information Phillips curve seems to have a strong internal propagation mechanism in response to a quickly dying out money growth shock in my DSGE model.

Inflation in the standard Calvo sticky price model jumps on impact to its maximum effect and then decreases monotonically. Although prices are sticky inflation is not. 
By contrast, inflation in the sticky price model with dynamic inflation indexation reacts with delay and gradually to a money growth shock since it is both - forward and backward looking. The maximum impact occurs around the 5th quarter and is somewhat more pronounced than in the sticky information model. However, sticky information and sticky prices with dynamic inflation indexation deliver the same qualitative results for my baseline parameterization.

To that end, I conclude that sticky information generates a delayed and gradual response of inflation to a money growth shock in my DSGE framework. Moreover, the sticky price model with dynamic inflation indexation is also able to deliver a hump-shaped response of inflation.

\subsubsection{Sensitivity}

My results depend, of course, on the parameters chosen in section 2.6. In this section, I set key parameters to values that represent reasonable bounds of parameter ranges used in the literature. This way, the section serves two purposes. First, it provides a sensitivity analysis for the results reported in the previous section. Second, and more importantly, it enables me to assess the effects of deep parameters of the model on the behavior of inflation especially for the sticky information model.

In particular, I examine how a high inverse Frisch elasticity of $\phi=6.7$ as in Pencavel (1986) respectively a low inverse Frisch elasticity of $\phi=0.47$ as used e.g. in Reis (2006) affects the dynamics of inflation in my models. Or baseline value of $\theta=6$ implies a steady state markup of 20 percent which represents an upper bound in the literature. Alternatively, I set $\theta=10$ as in Chari, Kehoe, and Mcgrattan (2000) as well as $\theta=7.88$ as in Rotemberg and Wodford (1997) which imply markups of roughly 11 and 15 percent. Further, my baseline choice of $\sigma=v=2$ implies a moderate degree of intertemporal substitution. Alternatively, I set $\sigma=v=1$ which implies log utility in consumption as in Gali (2003) and many others. Moreover, I also examine 
the case of high intertemporal substitution by setting $\sigma=v=0.5 .{ }^{15}$ Furthermore, I examine $\alpha=1$ as in Gali (2003) which results in a linear production technology in hours worked.

Finally, I also allow for variations in information and price rigidity governed by $\lambda_{i}$. In my baseline parameterization we set $\lambda_{i}=0.75$ which implies average information updates and price contracts of one year. Recent empirical literature suggests that these values might represent an upper bound. Therefore, I set $\lambda_{i}=0.66$ as well as $\lambda_{i}=0.5$ which implies average durations of price contracts respectively information updates of 3 and 2 quarters. For sticky price models 3 quarters are in line with Sbordone (2002) while 2 quarters reflect Altig, Christiano, Eichenbaum, and Linde (2004), Bils and Klenow (2004) and Golosov and Lucas (2003) who report that firms change prices on average roughly every 1.5 quarters. Finally, for sticky information models, recent work by e.g. Mankiw and Reis (2006b), Korenok (2004) and Korenok and Swanson (2006) suggest that average durations of information updates of 3 to 2 quarters may not be unrealistic for sticky information models.

Table 2 shows the quarter at which inflation peaks after a monetary policy shock in period $t=0$ for my alternative parameter choices. The table reveals that although the peak of inflation varies the sticky information model as well as the sticky price model with dynamic inflation indexation always generate a delayed response of inflation after a monetary policy shock. By contrast, in the standard Calvo sticky price model inflation peaks always on impact.

Let's examine the effects of deep parameters of the model for the behavior of inflation in the sticky information model. A higher value for $\theta$ implies a lower steady state markup and hence results in lower market power for firms. Accordingly, firms change prices less than they would with higher market power and thus inflation peaks later in the sticky information model. A higher value $\phi$ implies a lower Frisch

\footnotetext{
${ }^{15}$ Note that I set $\sigma=v$ in these cases because this implies a unit elasticity of money demand with respect to consumption as documented by the empirical literature, see Walsh (2003) for an excellent survey.
} 
elasticity of labor supply. Hence, changing labor inputs is more costly for firms in terms of the real wage and therefore they change prices by less which again results in a later peak of inflation. Lower values for $\sigma$ and $v$ result in a higher intertemporal elasticity of substitution and therefore lead to less consumption smoothing of households. Thus, aggregate demand displays a steeper intertemporal schedule which is accompanied by an earlier peak of inflation. In addition, a higher value $\alpha$ moves production towards a linear technology and reduces therefore the input costs of firms. Accordingly, inflation attains its peak earlier. Finally, lower values for $\lambda_{1}$ increase the fraction of firms that receive information updates. Therefore, more firms adjust their prices in response to the monetary policy shock which leads to an earlier peak of inflation in the sticky information model.

Finally, to ensure further robustness, I also consider joint variations of parameters. That is, I take many random draws for the parameter set $\left\{\theta, \phi, \sigma, v, \alpha, \lambda_{i}\right\}$ and generate the associated impulse responses of inflation for each set. In particular, to construct the above random parameter set, I draw each parameter from the following uniform distributions: $\theta \sim U[6,10], \phi \sim U[0.47,6.7], \sigma=v \sim U[0.5,2], \alpha \sim U[0.66,1]$, $\lambda_{i} \sim U[0.5,0.75]$. The intervals of the uniform distributions correspond to the ranges discussed above. I draw 5340 parameter sets and solve the models for each set. ${ }^{16}$ Figure 3 shows the corresponding impulse responses for each model. Further, I add my baseline impulse responses using white lines. In order to facilitate comparison with respect to the peak of inflation, I normalize all impulse responses such that the initial response is equal to one, i.e. $\hat{\pi}_{0}=1$. Figure 3 reveals that there is not a single response in which inflation is monotonically decreasing after a monetary policy shock in the sticky information model as well as the Calvo sticky price model with dynamic inflation indexation. In other words, there is always a hump-shape in inflation though it might be short lived. In particular, on average, the peak in the sticky information model occurs at quarter 4.2 while it occurs at quarter 3.4 in the sticky price model with dynamic inflation indexation. These figures are somewhat lower than the reported peaks at quarters 7 and 5 in my baseline sticky informa-

\footnotetext{
${ }^{16}$ This takes somewhat more than two weeks on an up-to-date unix machine.
} 
tion and sticky price with dynamic inflation indexation models. Nevertheless, both models appear to robustly deliver a delayed response of inflation after a monetary policy shock. By contrast, the standard Calvo sticky price model produces always a maximum response on impact. Finally, the white lines in figure 3 indicate that my baseline results do not represent an upper or lower bound but are located well within the set of impulse responses that is generated by random parameter draws.

Hence, my analysis shows, that although I vary key parameters in the model inflation reacts with delay to a monetary policy shock in the sticky information model. This is due to the fact that despite considerable parameter variations firms pricing decisions are strategic complements, i.e. $\zeta<1$. By contrast, Collard and Dellas (2006) as well as Keen (2005) introduce sticky information in alternative DSGE frameworks. These authors report that sticky information models generate maximum inflation responses on impact or at most one quarter after the monetary policy shock. These results occur since their DSGE frameworks imply that firms pricing decisions are strategic substitutes $(\zeta \geq 1)$ which produce the early peak of inflation. ${ }^{17}$ However, Woodford (2003) surveys and discusses the existing literature at length and concludes that firms pricing decisions should be strategic complements rather than strategic substitutes to allow for potential inflation inertia. Therefore, in this paper I allow for sufficient strategic complementarities in firms pricing decisions by employing a commonly used DSGE framework similar to Woodford (2003).

To sum up, my sensitivity analysis shows that the qualitative result of Mankiw and Reis (2002) is also robust in my DSGE framework: inflation reacts with delay and gradually to a monetary policy shock in the sticky information model whereas it does not in the standard Calvo sticky price model. Furthermore, I show that Calvo sticky prices with dynamic inflation indexation perform equally well as sticky information in my DSGE model.

\footnotetext{
${ }^{17}$ Note that Coibion (2006a) arrives at a similar conclusion.
} 


\subsubsection{Technology and Government Expenditure Shocks}

In the previous section I have concluded that inflation behaves inertial after a monetary policy shock. However, in the data inflation is likely to be affected by other disturbances such as supply and government spending shocks. How do they affect inflation in the sticky information model compared to the sticky price models? Mankiw and Reis (2002) are not able to analyze the consequences of these disturbances for the behavior of inflation since their partial equilibrium model did contain monetary policy disturbances only. However, my DSGE model enables me to investigate the effects of technology and government expenditure shocks. Figure 4 depicts the effects of a technology shock and figure 5 shows the response of the models to a government expenditure shock. Again, inflation peaks on impact in the standard Calvo sticky price model. By contrast, it appears that the reaction of inflation is inertial in the sticky information model in response to these disturbances. Note however, that for my baseline parameterization the peak of inflation occurs somewhat earlier and the hump is less pronounced compared to the monetary shock. Finally, the Calvo sticky price model with dynamic inflation indexation delivers a gradual and delayed response of inflation for technology and government expenditure shocks as well.

\subsubsection{A Thought Experiment}

Note that I arrive at the above conclusions for given exogenous processes for technology, government spending and money growth as supported by the data. All these processes display relatively high positive autocorrelations and hence shocks to these variables result in a relatively smooth adjustment over time. I do not claim that my findings are invariant to changes in the exogenous processes. Consider the following mind experiment. Imagine that policy behaves deterministically and increases money growth in all even periods and decreases it in all odd periods. Under this policy, sticky information and sticky prices with dynamic inflation indexation would appear to be very different. That is, sticky information firms would mimic the deterministic behavior of monetary policy by setting prices appropriately in all 
periods e.g. inflation would display a flip-flop pattern. By contrast, sticky price firms would need to set one average profit maximizing price which might then be adjusted smoothly due to dynamic inflation indexation and therefore inflation would still display a smooth pattern. Hence, under these circumstances, both models would appear very differently with respect to e.g. inflation.

However, given empirical evidence on e.g. money growth there does not seem to be a deterministic flip-flop pattern in money growth figures. Rather, money growth appears to be fairly smooth with an $\mathrm{AR}(1)$ coefficient around 0.5. Hence, although the upper example is illustrative, I consider it as a mind experiment which does not represent observed policy.

Again, given my DSGE model and given the observed exogenous processes sticky information and sticky prices with dynamic inflation indexation appear to perform equally well.

\subsection{Announced Disinflations}

In this section, I analyze the effects of a disinflation that is announced two years in advance. In particular, in period $t=0$ the central bank announces credibly that it will reduce money growth temporarily from period $t=2$ (respectively the 8 th quarter) onwards. The credibly announced fall in money growth is temporary in the sense that I assume the same stationary process for money growth as before. ${ }^{18}$ See appendix A.2 for the technical modeling details.

Figure 6 shows the impulse responses to the announced temporary fall in money growth. Again, my DSGE model confirms Mankiw and Reis (2002) result that in

\footnotetext{
${ }^{18}$ Hence, the disinflation in my experiment is temporary which implies that inflation returns to its steady state. Mankiw and Reis (2002) have considered a permanent reduction of money growth in their original model. I have recalculated the effects of a temporary disinflation in the original Mankiw and Reis (2002) model as well as considered a permanent disinflation in my model. None of my qualitative conclusions, however, changes when considering these alternative cases.
} 
the sticky information model a credibly announced disinflation is contractionary with respect to output. Interestingly, the Sticky Information Phillips curve leads to a gradual and delayed downward adjustment of inflation already in the announcement period. It should be stressed that this result is different from Mankiw and Reis (2002) finding. They show that there is absolutely no reaction of inflation in response to the announcement. In their model, variables react only when policy comes into place. By contrast, I show that inflation starts reacting already when the announcement is made. This is due to the existence of perfectly informed and forward looking households which smooth the drop of consumption over time. Despite the reduction of inflation in the pre-announcement period the disinflation still turns out to be contractionary due to perfectly informed forward looking households and an interest elastic real money demand equation. Since a similar argument applies for the sticky price models, I will explain the detailed mechanism below.

The standard New Keynesian Phillips curve generates an immediate downward jump of inflation whereas the New Keynesian Phillips curve with dynamic inflation indexation leads to a gradual and delayed downward adjustment of inflation in the announcement period. However, in both models, it turns out, that the announced disinflations are contractionary too. By contrast, Mankiw and Reis (2002) as well as Ball (1994) find that for standard Calvo sticky price models announced and credible disinflations cause booms rather than recessions. However, this result is not robust in my fully-fledged DSGE framework.

The reason that I observe a fall of output despite the fall of inflation in the announcement period are perfectly informed and forward looking households and real money demand that depends on the nominal interest rate in my DSGE model. Consider the rewritten log-linearized real money demand equation (22) from appendix A.1 assuming exogenous technology and exogenous government expenditures are constant:

$$
\hat{m}_{t}=\frac{\sigma}{s_{c} v} \hat{x}_{t}-\eta \hat{R}_{t}
$$


where $\eta=\frac{1}{v(\bar{R}-1)}$. The announced fall of inflation has two effects. First, it decreases the nominal interest rate. Second, it increases real money demand. So, it depends on the relative size of each effect, whether the output gap increases or decreases. As it turns out, the interest rate effect dominates for reasonable parametrizations. That is, even if I assume an empirically implausible interest rate elasticity of real money demand which is 25 times smaller then in my baseline parameterization (e.g. by setting $\sigma=v=50$ in equation (18) in section 2.6) still the interest rate effect dominates and thus the announced disinflation is contractionary with respect to output. ${ }^{19}$

Note, that for $\eta=0$ only the real money demand effect influences equation (20) and hence, the output gap increases in response to a credibly announced disinflation. Thus, it is the exogenously assumed quantity equation which is inelastic with respect to the nominal interest rate that produces the disinflationary boom in the sticky price models in Ball (1994) and Mankiw and Reis (2002). This leads me to conclude that credibly announced disinflations are contractionary even if inflation falls in the announcement period as soon as aggregate demand arises from an intertemporal household maximization problem and real money demand is elastic with respect to the nominal interest rate. It should be mentioned here that for a model with Taylor wage contracts Ascari and Rankin (2002) arrive at a similar conclusion.

To sum up, in this section, I have shown that credibly announced disinflations are contractionary in the sticky information as well as in the Calvo sticky price with and without dynamic inflation indexation models in my DSGE framework.

\subsection{Acceleration Phenomenon}

Similar to Mankiw and Reis (2002), table 3 provides values for the correlation between output and the annual change of inflation. I use logged and hp-filtered quar-

\footnotetext{
${ }^{19}$ Korenok and Swanson (2006) report a similar result. They show that the disinflationary boom occurs only for very low interest rate elasticities. As soon as the interest elasticity increases to reasonable values as reported in Lucas (2000) or Chari, Kehoe, and Mcgrattan (2000) - which are in line with my baseline parameterization - the disinflationary boom disappears and turns into a recession.
} 
terly US CPI (all items) and real GDP data from 1960:1 to 2001:4. As it turns out, the data suggest a positive correlation between output and the annual change of inflation of about 0.41 . For the models I obtain hp-filtered correlation figures by averaging the results of 250 simulations for each model with a simulation length equal to US data. Consider the first column of table 3. It reports the correlation for the models using all three shocks. The sticky information model generates a correlation of 0.55 . This is similar to Mankiw and Reis (2002) original partial equilibrium sticky information model which delivers a correlation of 0.43 . To that end, I conclude that sticky information in my DSGE model is able to replicate the third conventional view that vigorous economic activity speeds up inflation.

Interestingly, the Calvo sticky price model with dynamic inflation indexation produces a correlation of 0.66 . Hence, this model is qualitatively also able to explain the third conventional view and performs similar to the sticky information model. By contrast, the standard Calvo sticky price model generates only a very low correlation of about 0.05 . However, since monetary, fiscal and technology shocks have different effects I also compute the correlations if either one of the shocks is used. Columns 2, 3 and 4 reveal that the standard Calvo sticky price model generates a negative correlation for monetary and government expenditure shocks whereas the correlation is positive for technology shocks. Hence, it depends on the relative weight of the technology shock whether the standard Calvo sticky price model can generate the acceleration phenomenon. By contrast, the sticky information model as well as the Calvo sticky price model with dynamic inflation indexation imply positive correlations for all three shocks and thus I conclude that those models may be better suited to explain the third conventional view.

\subsection{Still Improvable...}

How well can the models explain the lead and lag behavior of e.g. inflation in the data? In order to examine this issue, we compare the hp-filtered crosscorrelations of variables to output in the model in the presence of technology, monetary and fiscal 
shocks with crosscorrelations in the data. ${ }^{20}$ Figure 7 reports that inflation lags up to 4-5 quarters behind output in the data. The standard Calvo sticky price model is not able to deliver this feature. By contrast, the sticky information model and the Calvo sticky price model with dynamic inflation indexation perform equally well and are able to match the empirical evidence for inflation quite well.

Although the behavior of inflation in the data can be captured by the sticky information and sticky price model with dynamic inflation indexation there are some shortcomings with respect to other variables. E.g. figure 7 shows that the crosscorrelation of nominal interest rates and real marginal costs with output cannot be explained within my framework. In order to account for this one might want to introduce sticky information in labor and asset markets to the model. Alternatively, limited participation and nominal labor market frictions may help to explain these facts. Further, the introduction of real frictions like habit formation might also help to improve the match with the data for these variables. Moreover, alternative monetary policy rules like Taylor-type interest rate feedback rules with and without interest rate smoothing, McCallum rules, a nominal income targeting rule etc. may help to further improve the performance of the model. Further, deriving optimal monetary policy and optimal simple and implementable monetary policy rules especially for the sticky information model might deliver further insightful results. However, all these extensions are beyond the scope of this paper and I leave them to future research.

\section{Discussion of Related Literature}

A substantial part of the literature attempts to explain the behavior of aggregate inflation in response to monetary policy changes by short-run nominal price rigidities, e.g. inabilities of firms to change prices optimally. A leading framework has been provided by Calvo (1983) and used e.g. by Woodford (1996), Yun (1996), Goodfriend

\footnotetext{
${ }^{20}$ I use quarterly hp-filtered US time series from 1960:1 to 2001:4. Inflation is the quarterly change in the $\log$ CPI (all items) and output is log real GDP.
} 
and King (1997), Clarida, Gali, and Gertler (1999) and Gali (2003). Walsh (2003) as well as Woodford (2003) provide excellent, extensive and comprehensive overviews about the sticky price literature respectively the resulting New Keynesian Phillips curve. However, common to this literature is that aggregate inflation in the standard Calvo sticky price model does not react with delay and gradually in response to a monetary policy shock. Empirical studies, see e.g. Gali and Gertler (1999) and Gali, Gertler, and Lopez-Salido (2005), suggest that lagged inflation is an important determinant for the New Keynesian Phillips curve. In order to account for this, Christiano, Eichenbaum, and Evans (2005) employ dynamic inflation indexation as a modification to the standard Calvo sticky price approach. Non-optimizing firms apply a rule of thumb by updating last period's price with yesterday's inflation rate. There are, of course, alternative approaches to indexation in the literature. Yun (1996) assumes indexation to steady state inflation. Although this leads to a vertical long-run Phillips curve the dynamics are still entirely forward looking and hence inflation behaves not inertial. Smets and Wouters (2003) and Giannoni and Woodford (2003) assume partial dynamic inflation indexation, i.e. firms update prices only with a fraction of past inflation. Interestingly, Smets and Wouters (2003) report evidence for partial inflation indexation in European data while Giannoni and Woodford (2003) find evidence for full inflation indexation in US data and thereby confirm Christiano, Eichenbaum, and Evans (2005) choice of full dynamic inflation indexation. To that end, I am most interested in the consequences of full dynamic inflation indexation for the dynamics of aggregate inflation. Therefore, my results can be interpreted as representing an upper bound compared to cases of partial dynamic inflation indexation.

An alternative strand of literature attempts to explain the behavior of inflation when firms face imperfect information. Phelps (1970) suggested a parable of an economy consisting of many islands that coexist under informational isolation. He demonstrated that in such an economy an increase in nominal expenditures through, e.g. monetary policy, increases employment and output. In his pioneering work, Lucas $(1972,1973)$ showed that the implied short-run inflation and unemployment tradeoff in the island model is consistent with rational expectations of economic agents. 
In particular, in his island model, firms have imperfect information about aggregate variables and must solve a signal-extraction problem. As a result, imperfect information has the potential to result in short-run monetary non-neutralities, e.g. leading to short-run output fluctuations. In other words, the island model generates a short-run Phillips curve trade-off despite the presence of rational expectations. In spite of this success, it turns out that the island model cannot replicate the observed persistence of output and inflation fluctuations in the data. Generating persistence in rational expectations models has become a central issue in the recent macroeconomic literature as we will see now.

Sims (2003) explores the implications of rational inattention in an economy. He finds, that if agents face a finite information processing capacity then they may rationally decide to observe available information imperfectly. He concludes, that rational inattention might be an important ingredient for models that attempt to account for observed macroeconomic behavior. Woodford (2002) employs the idea of rational inattention in a model in which firms observe the state of aggregate demand with an idiosyncratic error. He shows that the presence of this idiosyncratic "noisy information channel" leads to persistent effects of inflation and output in response to aggregate nominal disturbances. In a recent paper, Sims (2006) surveys the existing literature on rational inattention. Within this literature, Moscarini (2004) as well as Mackowiak and Wiederholt (2006) analyze the effects of rational inattention for the pricing behavior of firms. These authors find that firms may decide to observe available information imperfectly due to limited information flow capacity and hence, nominal shocks have persistent effects on aggregate inflation and output.

Mankiw and Reis (2002) also assume that firms face costs of acquiring, absorbing and processing information. However, in contrast to the rational inattention literature, they assume that firms receive information updates exogenously and infrequently. In other words, firms have an unlimited information processing capacity at times when they receive information updates and a zero information processing capacity otherwise. Thus, if no new information arrives, firms must use old information and 
are completely inattentive. This price setting behavior of sticky information firms is equivalent to write an entire plan of prices which in turn is similar to pricing policies described in Fischer (1977), Cespedes, Kumhof, and Parrado (2003), Benassy (2003) and Devereux and Yetman (2003). Interestingly, although their story is different, Benassy (2003) and Devereux and Yetman (2003) arrive at equilibrium equations that are very similar to Mankiw and Reis (2002). However, in both cases, aggregate demand is also static and independent of the nominal interest rate. By contrast, this paper incorporates sticky information in a DSGE framework that features the so called dynamic "New IS" equation and a real money demand equation that depends on the nominal interest rate, see Clarida, Gali, and Gertler (1999), Gali (2003) or Woodford (2003).

However, Mankiw and Reis (2002) show that their so-called sticky information model performs better than the frequently used Calvo sticky price model in explaining three conventional facts: i) inflation reacts gradually and with delay after a monetary policy shock, ii) announced disinflations are contractionary and iii) inflation accelerates with vigorous economic activity. In a recent paper, Reis (2006) shows that the so called sticky information Phillips curve in Mankiw and Reis (2002) can be microfounded in an environment in which firms face fixed and finite costs of acquiring information and thereby moving sticky information as proposed by Mankiw and Reis (2002) closer to the rational inattention literature.

Dupor and Tsuruga (2005) compare the effects of random duration information updating à la Calvo with a fixed duration information updating interval à la Taylor in an otherwise similar partial equilibrium model setup to Mankiw and Reis (2002). They find that inflation is less inertial and exhibits a rather odd looking hump-shape in response to a monetary policy shock when firms update their information at infrequent but fixed intervals. Collard and Dellas (2006) can be interpreted as an extension of the work by Dupor and Tsuruga (2005). These authors incorporate sticky information with fixed duration information update intervals à la Taylor in a DSGE framework. Furthermore, the authors analyze the predictions of their DSGE model 
when sticky prices à la Taylor are assumed instead. Interestingly, and in contrast to Dupor and Tsuruga (2005), Collard and Dellas (2006) find that inflation peaks on impact after a money growth shock in the sticky information model. Moreover, the authors obtain the same qualitative result when sticky prices à la Taylor are assumed. The reason for these results are that Collard and Dellas (2006) set up a DSGE model in which pricing decisions of firms are not strategic complements but strategic substitutes instead. In other words, in this case, after e.g. a monetary policy shock, newly informed firms adjust their prices to a larger extend than they would do in a perfectly informed environment. They do so, in order to compensate for those firms who keep setting prices based on outdated information. Hence, due to missing strategic complementarities of firms pricing decisions, inflation peaks on impact - regardless whether sticky information or sticky prices à la Taylor are assumed.

Recently, Keen (2005) incorporates sticky information with the original Mankiw and Reis (2002) information updates à la Calvo in an alternative DSGE framework compared to the one used this paper. Interestingly, Keen (2005) reports that sticky information generates a maximum inflation response at most one quarter after a money growth shock and on impact after a nominal interest rate shock. Similar to Collard and Dellas (2006), the DSGE model in Keen (2005) generates pricing decisions of firms that are strategic substitutes which produce the early peaks of inflation. However, Woodford (2003) reviews and discusses the existing literature at length and concludes that firms pricing decisions ought to be modeled as strategic complements rather than strategic substitutes in order to allow for potential inflation inertia. Therefore, I employ a commonly used DSGE framework which is closely related to the one developed in Woodford (2003). This DSGE framework allows for sufficient strategic complementarities in firms pricing decisions. I believe that this is an interesting DSGE framework since it represents a standard small-scale workhorse DSGE model for the analysis of e.g. monetary policy.

Moreover, Andres, Lopez-Salido, and Nelson (2005) analyze sticky price and sticky information models with respect to the natural rate hypothesis. Their main empir- 
ical result indicates that the estimated output gaps of the sticky price model with dynamic indexation and the sticky information model are very similar but different from standard output gap measures.

Mankiw and Reis (2003) examine the consequences of sticky information for wage setters in a partial equilibrium model. The authors find that disinflations and productivity slowdowns cause employment to fall below the level that would prevail under full information. Based on the predictions of the model, they argue that policies such as nominal income or nominal wage targeting lead to more stable employment than targeting prices of goods and services.

Recently, Mankiw and Reis (2006a) set up a macroeconomic general equilibrium model in which prices, wages and consumption are assumed to be set by using old and outdated information. Mankiw and Reis (2006a) show that this model of pervasive information stickiness is able to explain three facts about short-run economic fluctuations jointly: the acceleration phenomenon, real wage smoothness and the gradual response of real variables. Thus, adding sticky information to other markets seems to be important to explain further facts jointly. In a very recent paper, Mankiw and Reis (2006b) develop a medium-scale general equilibrium model with sticky information in price, wage and consumption choices in order to explain five key macroeconomic time series jointly. The authors propose a solution method which allows to estimate sticky information models with e.g. Bayesian model estimation methods. Their estimation results indicate that information rigidities are present for firms and especially important for workers and consumers in order to explain the five macroeconomic time series jointly.

Reis (2004) shows that a gradual and delayed response of consumption to news can be obtained in an environment in which households face costs of acquiring, absorbing and processing information. Coibion (2006a) integrates sticky information for consumers in a DSGE model and finds that this yields a more gradual and delayed adjustment of output which in turn amplifies inflation inertia. Moreover, he argues 
that the ability of sticky information to deliver inflation inertia depends on the underlying parameters of the model. Further, for sticky information firms, Coibion (2006a) reports that Taylor rules make inflation inertia less likely than money growth rules for random information rigidity durations. Interestingly, in the case that information rigidity has a fixed duration, the choice of the monetary policy rule appears to be of minor importance. However, these issues are beyond the scope of this paper. Instead, we employ the original Mankiw and Reis (2002) specification of random information rigidity duration and monetary policy that follows a money growth rule. Moreover, I examine how sticky information performs in general equilibrium and, more importantly, in comparison to Calvo sticky prices with dynamic inflation indexation. In addition, I am not only interested in the relative performance of the models with respect to inflation inertia but focus also on Mankiw and Reis (2002) other two measuring devices: announced and credible disinflations and the acceleration phenomenon.

Recently, a growing body of work attempts to assess the empirical support for the sticky information Phillips curve. Mankiw and Reis (2006a,b), Mankiw, Reis, and Wolfers (2004), Kahn and Zhu (2006), Caroll (2003) and Dovern, Doekpe, Fritsche, and Slacalek (2006) find empirical support for the sticky information Phillips curve. By contrast, Coibion (2006b) largely rejects its existence. Recently, and partly motivated by my work, further work attempts to examine the relative performance of sticky information versus sticky prices from an empirical point of view. Authors such as Korenok (2004), Kiley (2005), Dupor, Kitamura, and Tsuruga (2006), Laforte (2005) and Paustian and Pytlarczyk (2006) claim that sticky prices with dynamic inflation indexation perform empirically better than sticky information. Further, Coibion and Gorodnichenko (2006) report that the fraction of standard Calvo sticky price firms is three times as large as the fractions of sticky information or sticky price firms with dynamic inflation indexation. In contrast to these studies, Andres, Lopez-Salido, and Nelson (2005) report that a sticky information model yields a higher likelihood than a sticky price model with dynamic inflation indexation. Finally, the empirical results of Korenok and Swanson (2006) suggest that sticky information and sticky prices 
with dynamic inflation indexation perform equally well for reasonable degrees of information and price stickiness. Hence, their empirical study can be interpreted as delivering empirical evidence for the theoretical predictions of this paper.

However, it seems that the empirical literature has not yet agreed on whether sticky information matters at all or whether sticky information is outperformed by sticky prices with dynamic inflation indexation. This is an ongoing, lively and interesting debate. Given the variety of conflicting empirical evidence it seems that the results depend on the particular empirical approaches or model specifications. In particular, important issues in the work cited above are whether to test sticky information using aggregate or disaggregate data and even more importantly, how to proxy for inflation expectations of economic agents. Furthermore, the particular choice whether to use e.g. reduced form GMM estimation, minimum distance estimation or structural model estimations using Bayesian methods as provided e.g. by Julliard (2006) (DYNARE) appears to matter for the results. Moreover, model features such as the number of relevant lags of the sticky information Phillips curve, the inclusion of sticky information in other markets, the use of small-scale or medium-scale models with further nominal and real frictions have an impact on the empirical performance of the respective models. These issues together with the variety of conflicting empirical evidence leads me to conclude that the literature is not yet mature enough to conclude whether sticky prices outperform sticky information from an empirical point of view. An own explicit empirical assessment of my theoretical conclusions would require me to address these issues thoroughly and would certainly justify a separate piece of research. This, however, is is beyond the scope this paper.

Instead, this paper is designed as a first step from a theoretical point of view to examine the consequences of sticky information in a small-scale general equilibrium model which I then contrast with sticky prices with dynamic inflation indexation as in Christiano, Eichenbaum, and Evans (2005). More importantly and in line with Mankiw and Reis (2002), I explore the qualitative ability of the models to generate the three conventional effects. Put differently, the conventional effects itself are of rather 
qualitative nature and this paper is designed to analyze the models ability to reflect them qualitatively. In terms of the parameters chosen in this paper, I rely on standard values that are used in the literature. In addition, I pursue a sensitivity analysis to evaluate the robustness of the qualitative predictions of the sticky information model as well as the sticky price with and without dynamic inflation indexation models.

To sum up, the present paper contributes to the existing literature as follows. I show that sticky information as in Mankiw and Reis (2002) as well as sticky prices with dynamic indexation as in Christiano, Eichenbaum, and Evans (2005) are both able to replicate the conventional wisdom with respect to inflation inertia, announced disinflations and the acceleration phenomenon in a DSGE model. I arrive at this conclusion by comparing the respective models in a parameterized standard smallscale DSGE framework similar to Woodford (2003).

\section{Conclusion}

Mankiw and Reis (2002) have proposed sticky information as an alternative to Calvo sticky prices in order to model the conventional view that i) inflation reacts with delay and gradually to a monetary policy shock, ii) announced and credible disinflations are contractionary and iii) inflation accelerates with vigorous economic activity. I use a fully-fledged DSGE model with sticky information and compare the results to those when Calvo sticky prices with and without dynamic inflation indexation are assumed instead.

Regarding the sticky information model my results confirm the finding by Mankiw and Reis (2002): all three effects listed above can be replicated in my baseline DSGE model as well. A sensitivity analysis reveals that this result is robust with respect to parameter variations. However, general equilibrium features such as forward looking households and interest elastic money demand are nevertheless important. In particular, I find that e.g. inflation and the output gap in the sticky information 
model react already in the announcement periods to an announced disinflation due to consumption smoothing households and interest elastic money demand in general equilibrium. Further, I show that a Calvo sticky price model without dynamic inflation indexation can already match the conventional view that announced and credible disinflations are contractionary due to the existence of interest elastic money demand in general equilibrium in my baseline DSGE model. This result appears to be robust within my DSGE framework. Finally, I allow for dynamic inflation indexation in the Calvo sticky price model and show that in my baseline DSGE framework this works just as well as sticky information in delivering all three effects. Again, my result appears to be robust to variations in key structural parameters of the model.

I conclude that sticky information as in Mankiw and Reis (2002) as well as sticky prices with dynamic inflation indexation as in Christiano, Eichenbaum, and Evans (2005) are perfectly capable of replicating the conventional wisdom with respect to inflation inertia, announced disinflations and the acceleration phenomenon in the DSGE model used in this paper. However, the source of e.g. inflation inertia in both models is different. In the sticky information model, inflation inertia arise due to slow information diffusion. In the sticky price model with dynamic inflation indexation, inflation inertia is hard-wired by assuming that non-optimizing firms index prices to past inflation. Hence, these firms use a very limited outdated information set. From that perspective, one might want to view information stickiness as providing a micro foundation for the particular choice of dynamic inflation indexation in Calvo sticky price models. Although both models perform equally well with respect to my measures, I believe that sticky information might be better suited to explain the underlying micro behavior of price setting firms.

\section{References}

Abel, A. B., And B. S. Bernanke (1998): Macroeconomics. Addison-Wesley, 3rd edn.

Altig, D., L. J. Christiano, M. Eichenbaum, And J. Linde (2004): “Firm-Specific Capital, Nominal Rigidities And The Business Cycle," Manuscript. 
Andres, J., D. J. Lopez-Salido, And E. Nelson (2005): “Sticky Price Models And The Natural Rate Hypothesis," Journal Of Monetary Economics, 52(5), 1025-1053.

Ascari, G. (2004): "Staggered Prices And Trend Inflation: Some Nuisances," Review Of Economic Dynamics, 7(3), 642-667.

Ascari, G., AND N. RanKin (2002): “Staggered Wages And Output Dynamics Under Disinflation," Journal Of Economic Dynamics And Control, 26, 653-680.

Backus, D. K., P. J. Kehoe, AND F. E. Kydland (1995): “International Business Cycles: Theory And Evidence," Frontiers Of Business Cycle Research, Ed. Thomas F. Cooley, Princeton University Press, pp. 331-356.

Ball, L. (1994): “Credible Disinflation With Staggered Price Setting," American Economic Review, 84, 282-289.

Benassy, J. P. (2003): “Output And Inflation Dynamics Under Price And Wage Staggering: Analytical Results," Annales DÉconomie Et De Statistique, 63, 1-30.

Bils, M., AND P. Klenow (2004): “Some Evidence On The Importance Of Sticky Prices," Journal Of Political Economy, 112, 947-985.

Calvo, G. (1983): “Staggered Prices In A Utility-Maximizing Framework," Journal Of Monetary Economics, 12, 383-398.

Caroll, C. D. (2003): “Macroeconomic Expectations Of Households And Professional Forecasters," Quarterly Journal Of Economics, 118(1), 269-298.

Cespedes, L., M. Kumhof, and E. Parrado (2003): “Pricing Policies And Inflation Inertia," IMF Working Papers, (03/87).

Chari, V. V., P. J. Kehoe, and E. R. Mcgrattan (2000): “Sticky Price Models Of The Business Cycle: Can The Contract Multiplier Solve The Persistence Problem?," Econometrica, 68, 1151-1180.

Christiano, L. J., M. Eichenbaum, and C. Evans (2005): “Nominal Rigidities And The Dynamic Effects Of A Shock To Monetary Policy," Journal Of Political Economy, 113(1), 1-45. 
Clarida, R., J. Gali, and M. Gertler (1999): “The Science Of Monetary Policy: A New Keynesian Perspective," Journal Of Economic Literature, 37, 1661-1707.

Coibion, O. (2006a): “Inflation Inertia In Sticky Information Models," Contributions In Macroeconomics, 6(1).

(2006b): “Testing The Sticky Information Phillips Curve," Manuscript.

Coibion, O., AND Y. GorodnichenKo (2006): “Strategic Interaction Among Heterogeneous Price Setters In An Estimated DSGE Model," Manuscript.

Collard, F., ANd H. Dellas (2006): “Sticky Information," Manuscript.

Devereux, M. B., and J. Yetman (2003): “Predetermined Prices And The Persistent Effects Of Money On Output," Journal Of Money, Credit, And Banking, 35(5), 729741.

Dovern, J., J. Doekpe, U. Fritsche, and J. Slacalek (2006): “Sticky Information Phillips Curves: European Evidence," DIW Discussion Papers, (615).

Dupor, B., T. Kitamura, and T. Tsuruga (2006): “Do Sticky Prices Need To Be Replaced With Sticky Information?," Manuscript.

Dupor, B., AND T. Tsuruga (2005): “Sticky Information: The Impact Of Different Information Updating Assumptions," Journal Of Money, Credit And Banking, 37(6), $1143-1152$.

Fischer, S. (1977): “Long-Term Contracts, Rational Expectations, And The Optimal Money Supply Rule," Journal Of Political Economy, 85(1), 191-205.

Gali, J. (2003): “New Perspectives On Monetary Policy, Inflation And The Business Cycle," Advances In Economic Theory, Edited By: M. Dewatripont, L. Hansen, And S. Turnovsky, Cambridge University Press, 3, 151-197.

Gali, J., ANd M. Gertler (1999): “Inflation Dynamics: A Structural Econometric Approach," Journal Of Monetary Economics, 44(2), 195-222. 
Gali, J., M. Gertler, ANd D. J. Lopez-Salido (2001): “European Inflation Dynamics," European Economic Review, 45(7), 1237-1270.

(2005): “Robustness Of The Estimates Of The Hybrid New Keynesian Phillips Curve," Journal Of Monetary Economics, 52, 1107-1118.

Gali, J., And T. Monacelli (2005): “Monetary Policy And Exchange Rate Volatility In A Small Open Economy," Review Of Economic Studies, 72, 707-734.

Giannoni, M. P., ANd M. Woodford (2003): “Optimal Inflation Targeting Rules,” $B$. S. Bernanke And M. Woodford, Eds. Inflation Targeting, University Of Chicago Press.

Golosov, M., And R. E. Lucas (2003): “Menu Costs And Phillips Curves," NBER Working Paper.

Goodfriend, M., AND R. G. King (1997): “The New Neoclassical Synthesis And The Role Of Monetary Policy," NBER Macroeconomic Annual 1997, Eds. Ben S. Bernanke And Julio J. Rotemberg, Cambridge And London: Mit Press, pp. 231-283.

Julliard, M. (2006): “Dynare,” http://www.cepremap.cnrs.fr/dynare/.

KaHN, H., ANd Z. Zhu (2006): “Estimates Of The Sticky-Information Phillips Curve For The United States," Journal Of Money, Credit And Banking, 38(1), 195-208.

Keen, B. D. (2005): “Sticky Price And Sticky Information Price Setting Models: What Is The Difference?," Forthcoming Economic Inquiry.

KILEY, M. (2005): “A Quantitative Comparison Of Sticky-Price And StickyInformation Models Of Price Setting," Manuscript.

KorenoK, O. (2004): “Empirical Comparison Of Sticky Prices And Sticky Information Models," Manuscript.

KorenoK, O., and N. R. Swanson (2006): “How Sticky Is Sticky Enough? A Distributional And Impulse Response Analysis Of New Keynesian DSGE Models," Forthcoming Journal Of Money, Credit And Banking. 
LAforte, J. P. (2005): “Pricing Models: A Bayesian DSGE Approach For The US Economy," Manuscript.

LucAs, R. E. (1972): “Expectations And The Neutrality Of Money," Journal Of Economic Theory, 4, 103-124.

(1973): “Some International Evidence on Output-Inflation Tradeoffs," American Economic Review, 63, 326-334.

— (2000): “Inflation And Welfare," Econometrica, 68(2), 247-274.

Mackowiak, B., ANd M. Wiederholt (2006): “Optimal Sticky Prices Under Rational Inattention," Manuscript.

Mankiw, G. N., AND R. ReIs (2002): “Sticky Information Versus Sticky Prices: A Proposal To Replace The New Keynesian Phillips Curve," Quarterly Journal Of Economics, 117(4), 1295-1328.

(2003): “Sticky Information: A Model Of Monetary Non-Neutrality And Structural Slumps," Knowledge, Information, And Expectations In Modern Macroeconomics: In Honor Of Edmund S. Phelps, Edited By P. Aghion, R. Frydman, J. Stiglitz And M. Woodford, Princeton University Press.

(2006a): "Pervasive Stickiness," American Economic Review Papers And Proceedings, 96(2).

(2006b): “Sticky Information In General Equilibrium," Forthcoming Journal Of The European Economic Association.

Mankiw, G. N., R. Reis, AND J. Wolfers (2004): “Disagreement About Inflation Expectations," NBER Macroeconomics Annual 2003, Mit Press.

MoscarinI, G. (2004): “Limited Information Capacity As A Source Of Inertia," Journal Of Economic Dynamics And Control, 28, 2003-2035.

Paustian, M., ANd E. PytlarczyK (2006): “Sticky Contracts Or Sticky Information? Evidence From An Estimated Euro Area DSGE Model," Manuscript. 
Pencavel, J. (1986): “Labor Supply Of Men: A Survey," Handbook Of Labor Economics, O. Ashenfelter And R. Layard, Eds., North-Holland, Amsterdam, 1.

Phelps, E. S. (1970): Microeconomic Foundations Of Employment And Inflation Theorychap. Introduction: The New Microeconomics In Employment And Inflation Theory. Norton.

ReIs, R. (2004): “Inattentive Consumers," Forthcoming Journal Of Monetary Economics. _ (2006): “Inattentive Producers," Review Of Economic Studies, 73(3), 793-821.

Rotemberg, J., AND M. Wodford (1997): “An Optimization-Based Econometric Framework For The Evaluation Of Monetary Policy," NBER Macroeconomics Annual 1997, pp. 297-346.

Sbordone, A. M. (2002): “Prices And Unit Labor Costs: A New Test Of Price Stickiness," Journal Of Monetary Economics, 49, 265-292.

Sims, C. A. (2003): "Implications Of Rational Inattention," Journal Of Monetary Economics, 50, 665-690.

_ (2006): “Rational Inattention: A Research Agenda," Manuscript.

Smets, F., AND R. Wouters (2003): “An Estimated Dynamic Stochastic General Equilibrium Model Of The Euro Area," Journal Of The European Economic Association, 1(5), 1123-1175.

Uhlig, H. (1999): “A Toolkit For Analyzing Nonlinear Dynamic Stochastic Models Easily," Computational Methods For The Study Of Dynamic Economies, (R. Marimon And A. Scott, Eds), Oxford University Press, Oxford, pp. 30-61.

Walsh, C. (2003): Monetary Theory And Policy. MIT Press, 2 edn.

WANG, P., AND Y. Wen (2006): “Solving Linear Difference Systems With Lagged Expectations By A Method Of Undetermined Coefficients," Manuscript.

Woodford, M. (1996): “Control Of The Public Debt: A Requirement For Price Stability?," NBER Working Paper. 
(2002): Imperfect Common Knowledge And The Effect Of Monetary Policy, In: Knowledge, Information, And Expectations In Modern Macroeconomics: In Honor Of Edmund S. Phelps. Princeton University Press.

(2003): "Interest And Prices: Foundations Of A Theory Of Monetary Policy," Princeton University Press.

Yun, T. (1996): “Nominal Price Rigidity, Money Supply Endogeneity, And Business Cycles," Journal Of Monetary Economics, 37, 345-370. 
Table 1: Baseline Parameterization of the DSGE Model

\begin{tabular}{|c|c|c|}
\hline Variable & Value & Description \\
\hline$\beta$ & 0.99 & Subjective discount factor \\
\hline$\sigma$ & 2 & Relative risk aversion \\
\hline$\phi$ & 1.5 & Inverse Frisch elasticity \\
\hline$v$ & 2 & Elasticity of real money balances \\
\hline$\alpha$ & $\frac{2}{3}$ & Labor share \\
\hline$\lambda_{i}$ & 0.75 & Price stickiness resp. information rigidity \\
\hline$\frac{\theta}{\theta-1}$ & 1.2 & Steady state markup of 20 percent \\
\hline$s_{c}$ & 0.7 & Consumption to output ratio in steady state \\
\hline $\bar{\Pi}$ & 1 & Steady state gross inflation \\
\hline$\rho_{z}, \sigma_{z}$ & $0.95,0.71$ & Technology shock \\
\hline$\rho_{\tilde{\xi}}, \sigma_{\xi}$ & $0.50,0.80$ & Money growth shock \\
\hline$\rho_{g}, \sigma_{g}$ & $0.95,0.60$ & Government expenditures shock \\
\hline
\end{tabular}


Table 2: Sensitivity Analysis: The Peak of Inflation

\begin{tabular}{llcccccccc}
\hline \hline & & \multicolumn{3}{c}{$\theta$} & \multicolumn{4}{c}{$\phi$} & \multicolumn{3}{c}{$\sigma=v$} & $\alpha$ \\
& & baseline & 10 & 7.88 & 6.7 & 0.47 & 1.0 & 0.5 & 1.0 \\
\hline \multirow{3}{*}{$\lambda_{i}=0.75$} & sticky information & 7 & 8 & 8 & 8 & 5 & 5 & 3 & 5 \\
& sticky prices (index) & 5 & 6 & 5 & 6 & 4 & 4 & 3 & 4 \\
& sticky prices & $\mathbf{0}$ & 0 & 0 & 0 & 0 & 0 & 0 & 0 \\
\hline \multirow{3}{*}{$\lambda_{i}=0.66$} & sticky information & 5 & 6 & 5 & 6 & 3 & 3 & 2 & 4 \\
& sticky prices (index) & 4 & 4 & 4 & 4 & 3 & 3 & 2 & 3 \\
& sticky prices & 0 & 0 & 0 & 0 & 0 & 0 & 0 & 0 \\
\hline \multirow{3}{*}{$\lambda_{i}=0.50$} & sticky information & 2 & 3 & 3 & 3 & 2 & 2 & 1 & 2 \\
& sticky prices (index) & 2 & 3 & 2 & 3 & 2 & 2 & 1 & 2 \\
& sticky prices & 0 & 0 & 0 & 0 & 0 & 0 & 0 & 0 \\
\hline \hline
\end{tabular}

Notes: Quarter at which inflation achieves the peak after a money growth shock for alternative parameter choices. The baseline parameters correspond to my baseline parameterization i.e. $\theta=6$, $\phi=1.5, \sigma=v=2, \alpha=2 / 3$. 
Table 3: Acceleration Phenomenon: Models vs. Data

\begin{tabular}{llccc}
\hline \hline & \multicolumn{4}{c}{ Corr $\left(\hat{y}_{t}, \hat{\pi}_{t+2}-\hat{\pi}_{t-2}\right)$} \\
& all shocks & $\begin{array}{l}\text { mon. } \\
\text { shock }\end{array}$ & $\begin{array}{l}\text { gov. } \\
\text { shock }\end{array}$ & $\begin{array}{l}\text { tech. } \\
\text { shock }\end{array}$ \\
\hline sticky information (DSGE) & $\mathbf{0 . 5 5}$ & 0.60 & 0.31 & 0.61 \\
sticky prices (Index), (DSGE) & $\mathbf{0 . 6 6}$ & 0.72 & 0.51 & 0.65 \\
sticky prices (DSGE) & $\mathbf{0 . 0 5}$ & -0.002 & -0.13 & 0.56 \\
\hline sticky information (Mankiw-Reis) & $\mathbf{0 . 4 3}$ & - & - & - \\
sticky prices (Mankiw-Reis) & $\mathbf{- 0 . 1 3}$ & - & - & - \\
\hline data & $\mathbf{0 . 4 1}$ & & & \\
\hline \hline
\end{tabular}

Notes: Acceleration phenomenon: correlation of output with the annual change of inflation. I use logged and hp-filtered quarterly US CPI (all items) and real GDP data. I obtain hpfiltered crosscorrelation figures by averaging the results for 250 simulations for each model with a simulation length equal to US data.

The source of uncertainty in the Mankiw and Reis (2002) model is an exogenous money supply shock. However, in their model this shock can also be interpreted as a shock to nominal income so that I report their results here at the column "all shocks". 
Figure 1: Illustrating the Solution Method
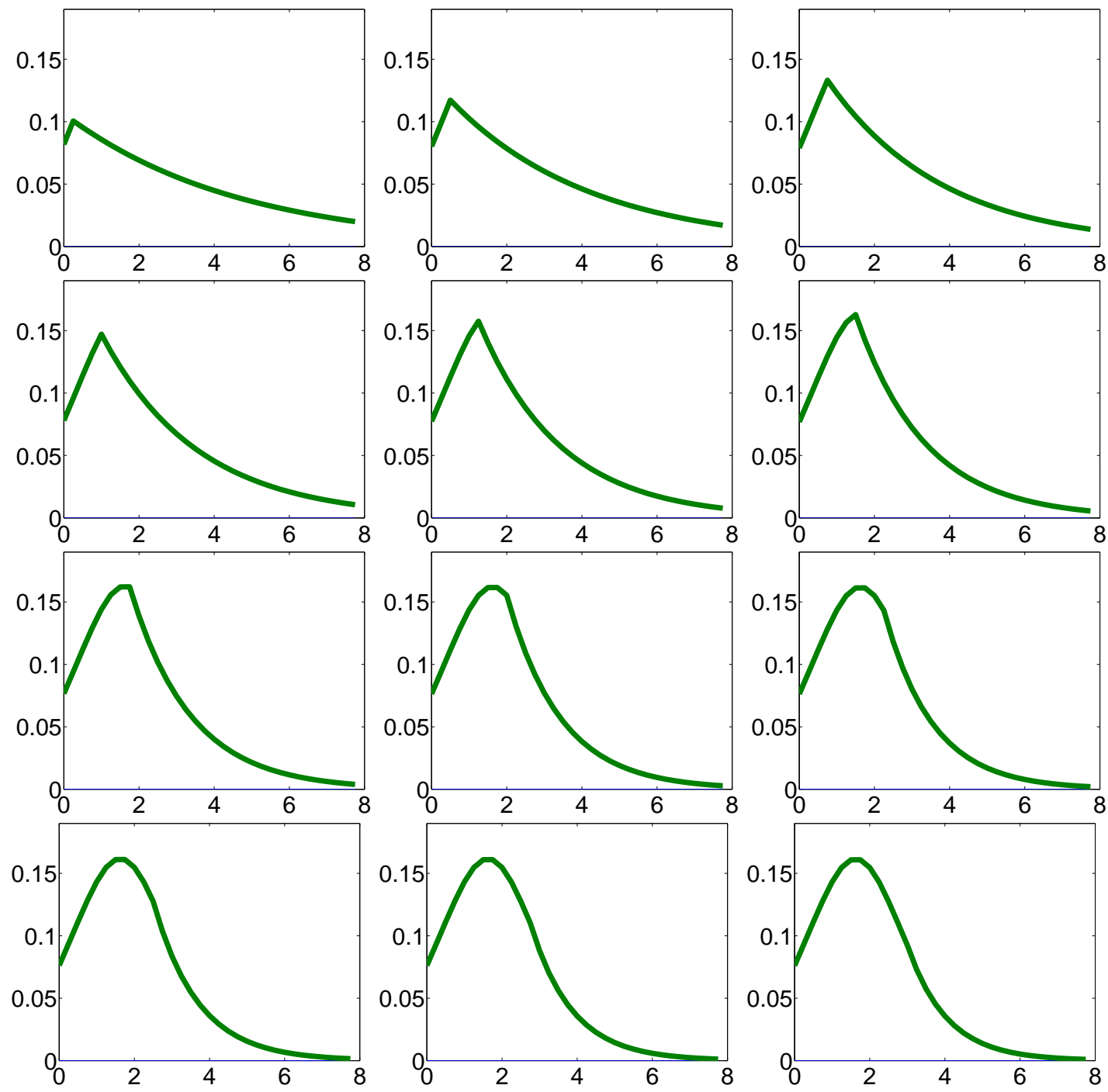

Notes: Impulse responses of inflation to a money growth shock for a stepwise inclusion of lagged expectations in the Sticky Information Phillips curve. The first plot in the top row shows the response of inflation if the model uses $\hat{\pi}_{t}=\frac{1-\lambda_{1}}{\lambda_{1}} \zeta \hat{x}_{t}+\left(1-\lambda_{1}\right) E_{t-1}\left[\hat{\pi}_{t}+\zeta \triangle \hat{x}_{t}\right]$. The next plot depicts the response of inflation if the model uses $\hat{\pi}_{t}=\frac{1-\lambda_{1}}{\lambda_{1}} \zeta \hat{x}_{t}+\left(1-\lambda_{1}\right) E_{t-1}\left[\hat{\pi}_{t}+\zeta \triangle \hat{x}_{t}\right]+(1-$ $\left.\lambda_{1}\right) \lambda_{1} E_{t-2}\left[\hat{\pi}_{t}+\zeta \triangle \hat{x}_{t}\right]$ etc. The $x$-axis plots years, the $y$-axis plots percent deviations from steady state. 
Figure 2: Impulse Responses to a 1\% Shock in Money Growth
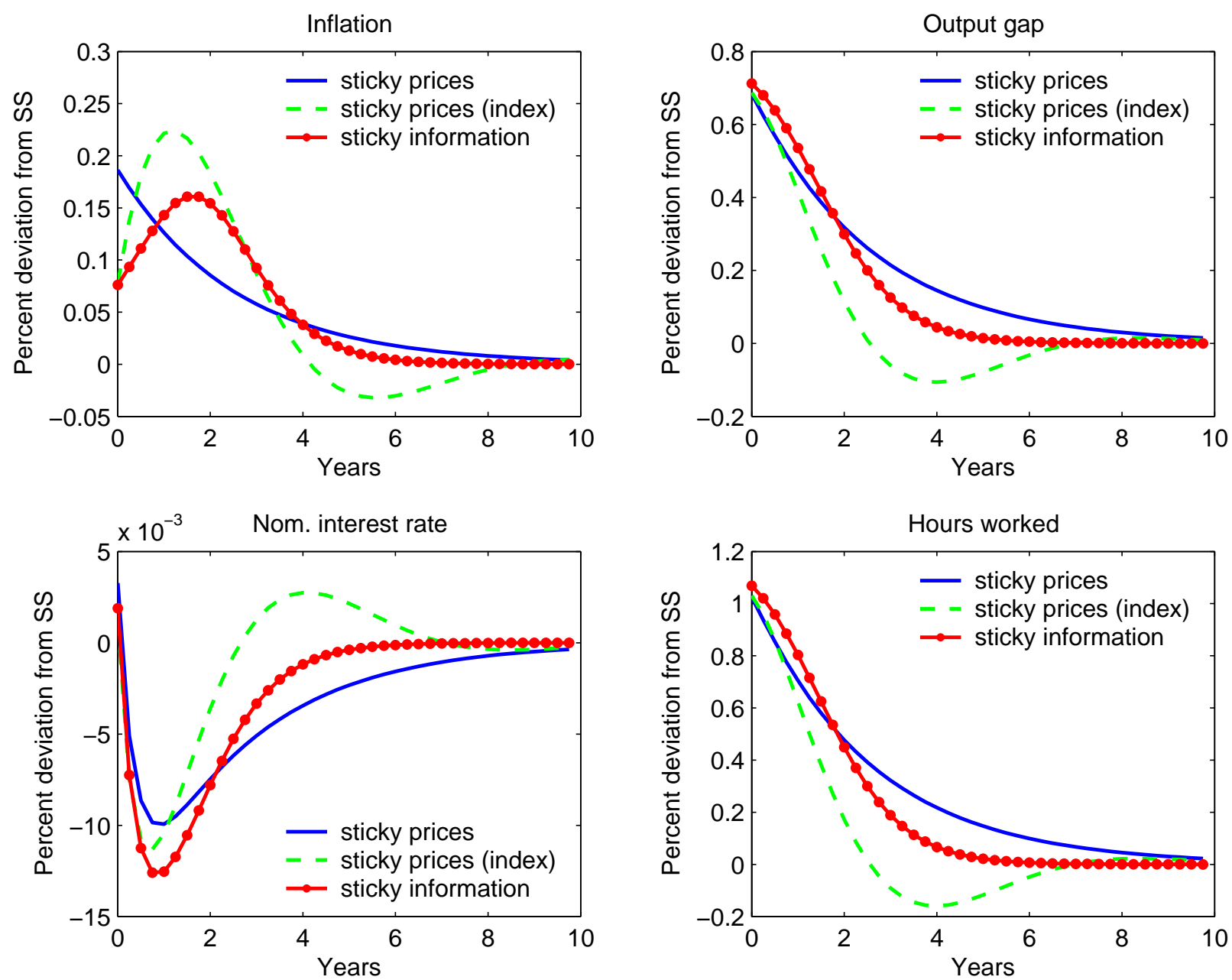
Figure 3: Sensitivity: Inflation Responses to a 1\% Shock in Money Growth
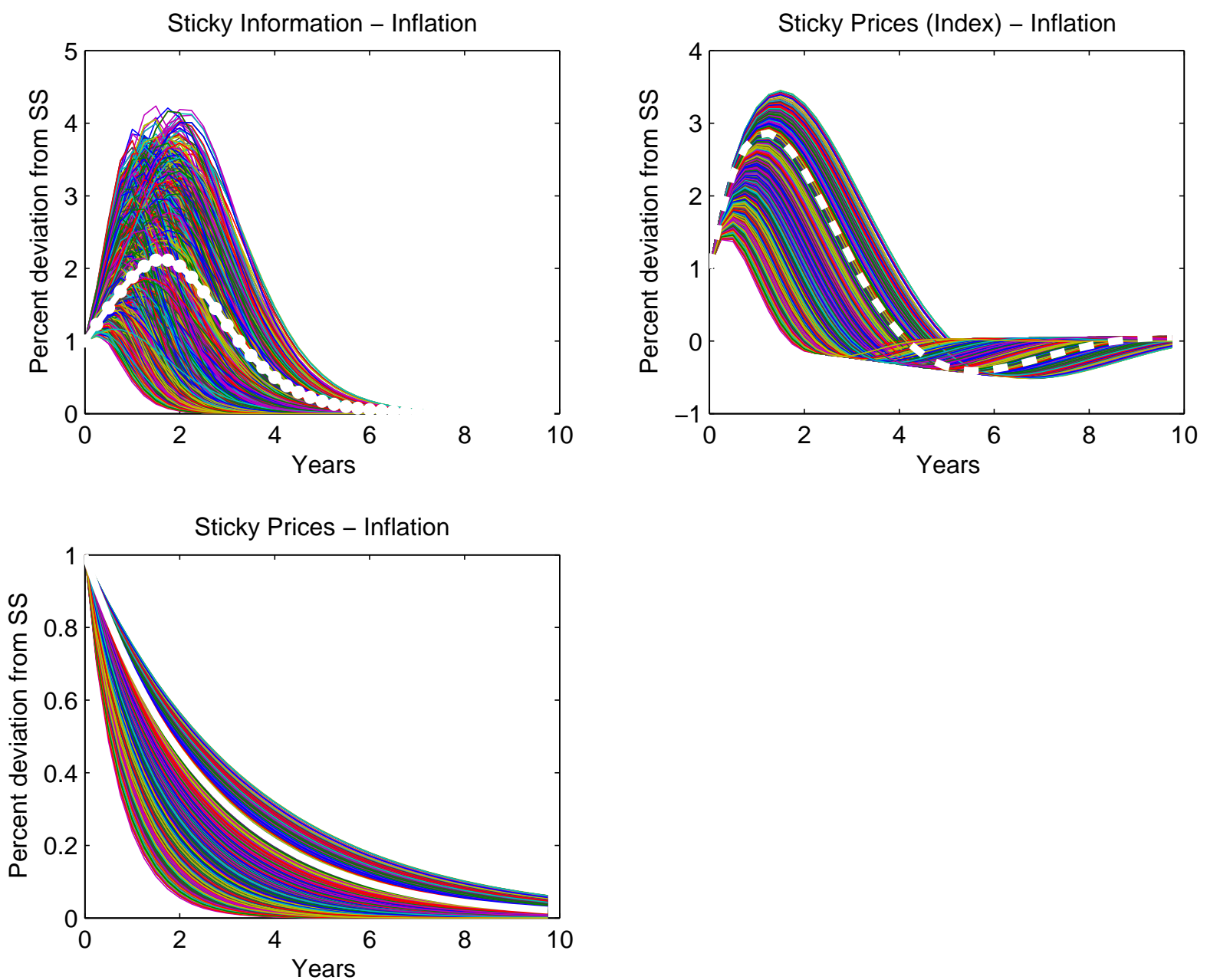

Notes: Sensitivity of inflation after a money growth shock. Each impulse response is generated after parameters have been drawn from the following uniform distributions: $\theta \sim U[6,10], \phi \sim$ $U[0.47,6.7], \sigma=v \sim U[0.5,2], \alpha \sim U[0.66,1], \lambda_{i} \sim U[0.5,0.75]$. Total number of drawn parameter sets: 5340 . The white lines show the baseline impulse responses of my model. In order to facilitate comparison with respect to the peak of inflation, I normalize all impulse responses such that the initial inflation response is equal to one, i.e. $\hat{\pi}_{0}=1$. 
Figure 4: Impulse Responses to a 1\% Shock in Technology
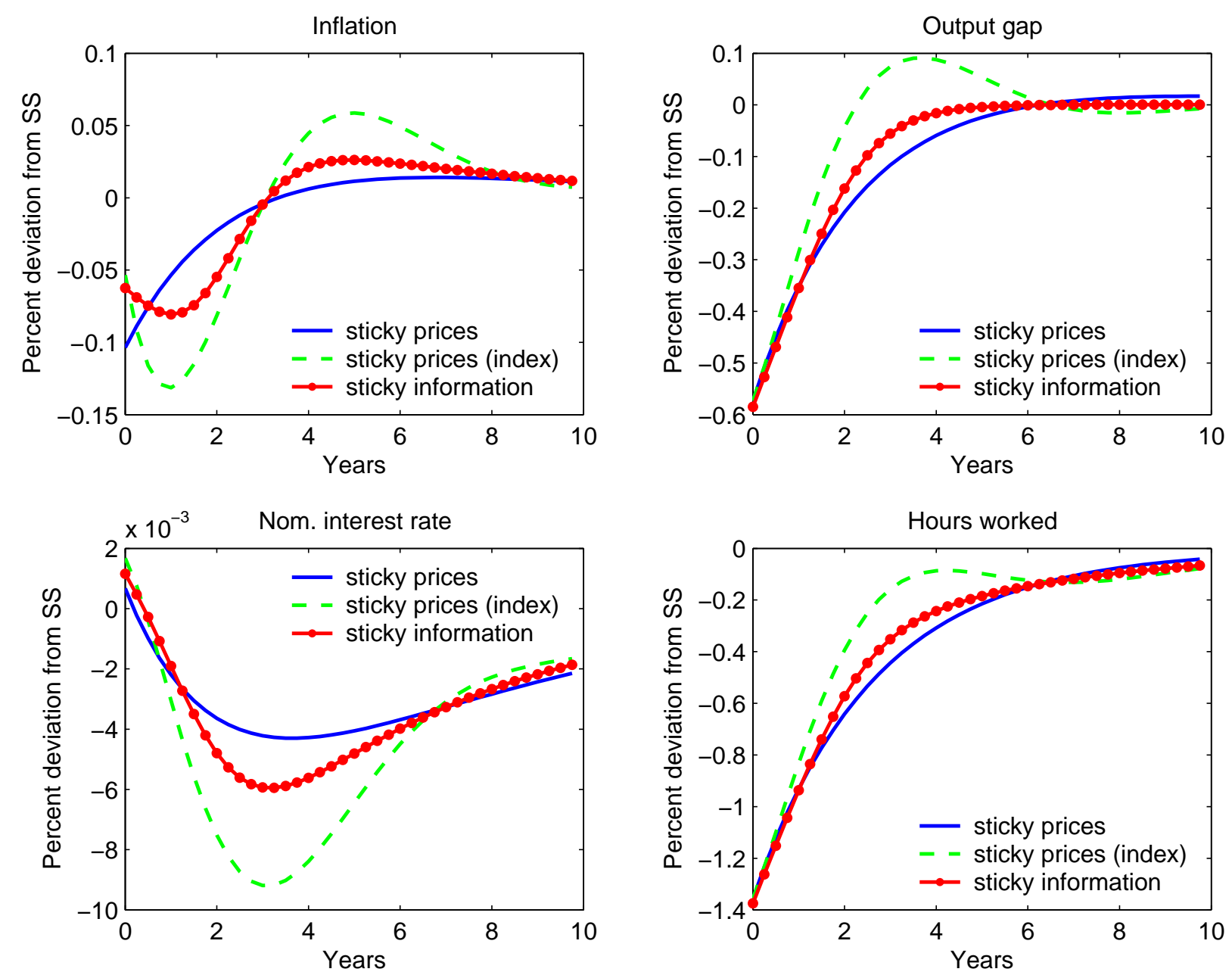
Figure 5: Impulse Responses to a 1\% Shock in Government Expenditures
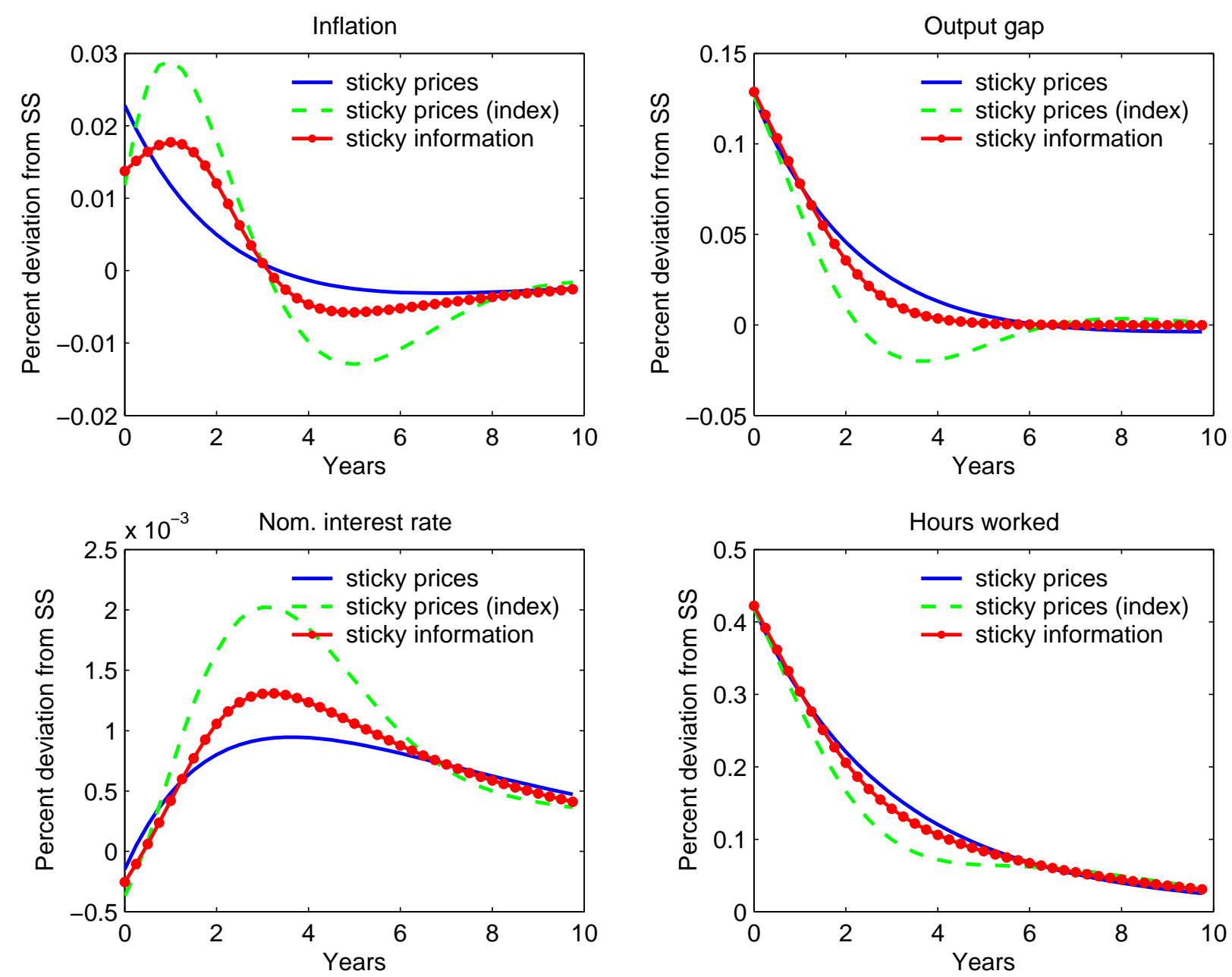
Figure 6: Impulse Responses to a Credibly Announced Disinflation
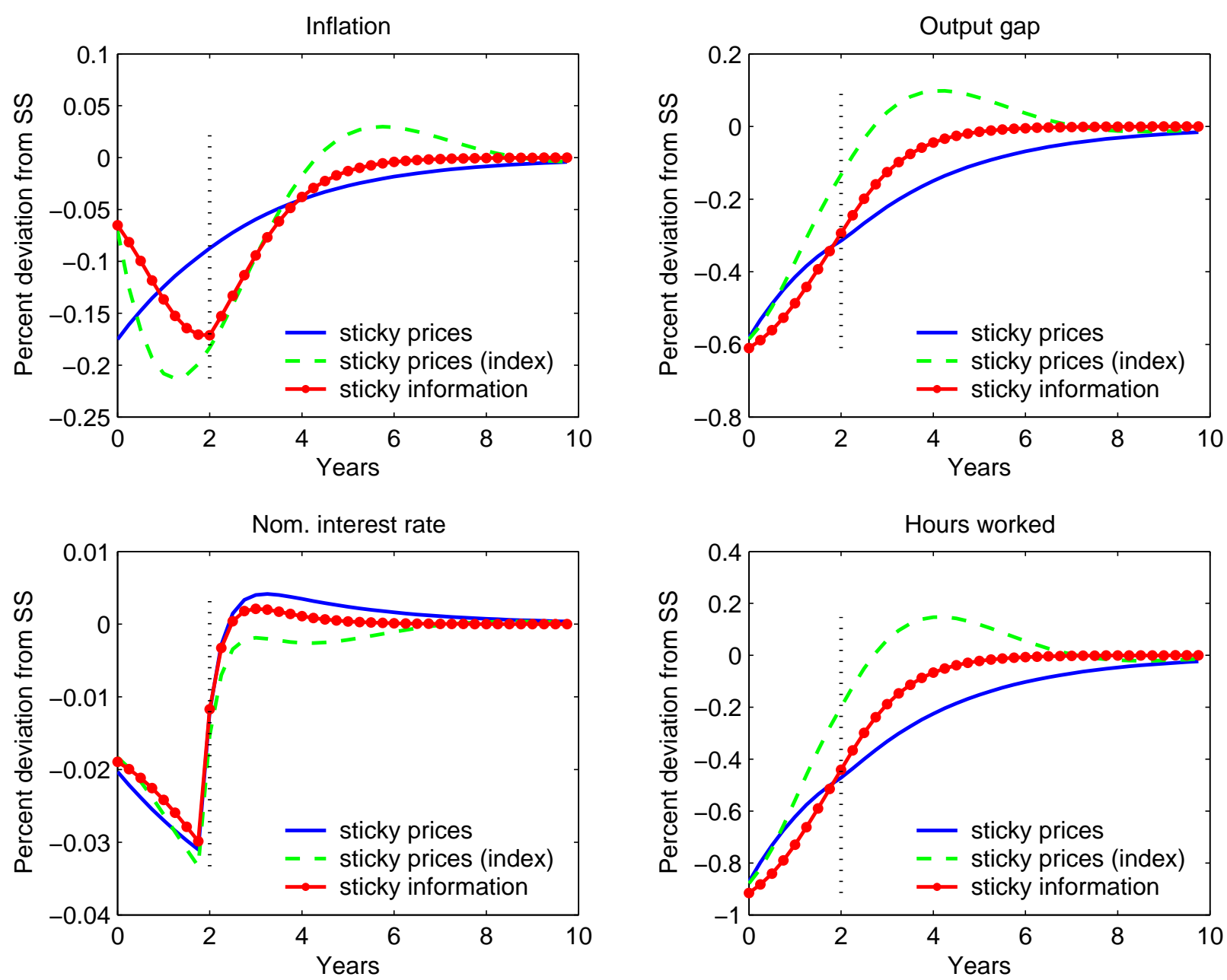

Notes: Impulse responses of model variables to a credible announcement at $t=0$ that money growth will fall temporarily from period $t=2$ onwards. 
Figure 7: Crosscorrelation of Variables $(t+j)$ with Output $(t)$
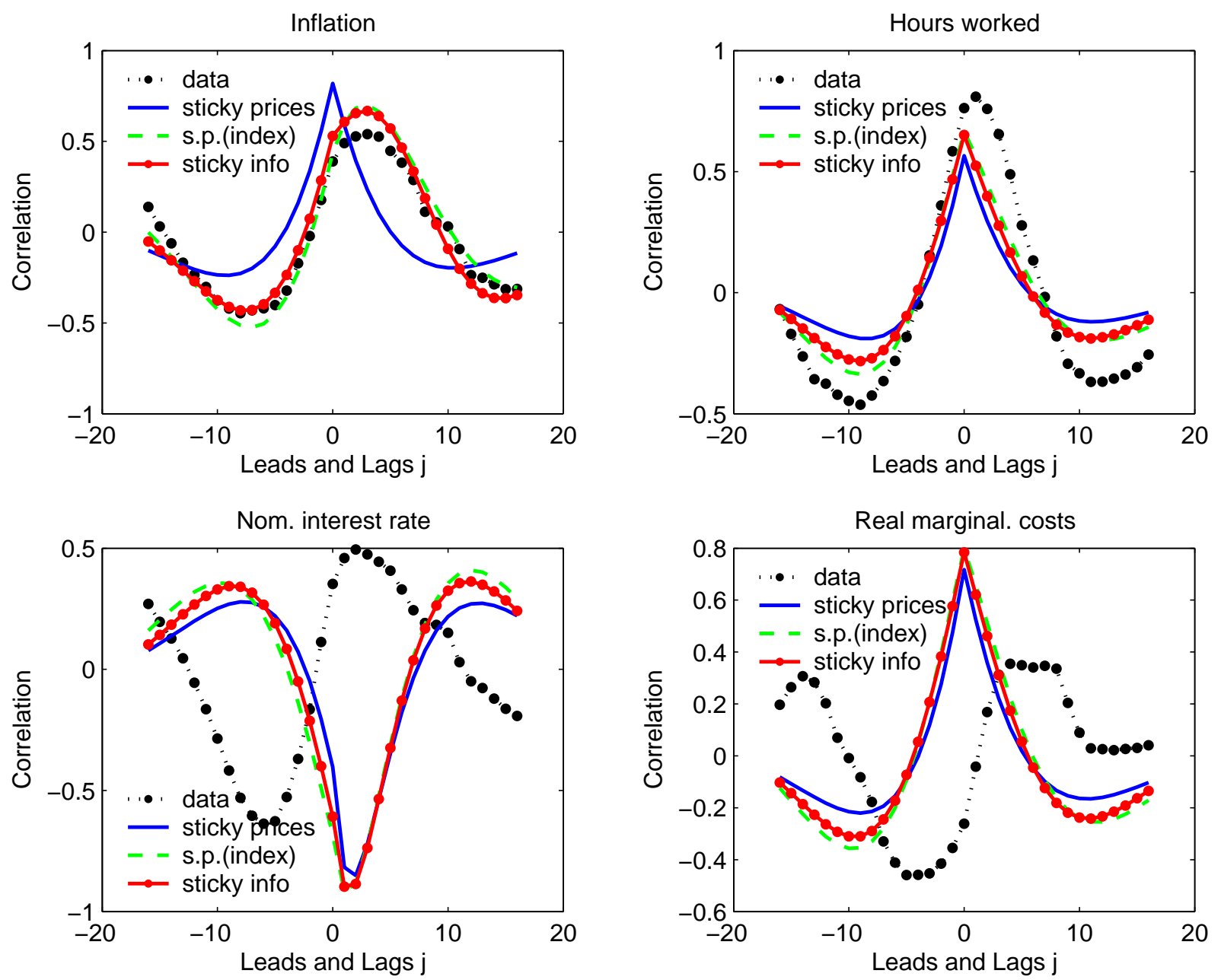

Notes: Frequency domain techniques are used to obtain crosscorrelations for the model variables. I use quarterly hp-filtered US time series from 1960:1 to 2001:4 (all in logs). Inflation is the quarterly change in the CPI (all items). The nominal interest rate is a three month government bond yield. I use a manufacturing employment index for hours worked. Output is real GDP and real marginal cost are CPI deflated unit labor cost. 


\section{A Appendix}

\section{A.1 The DSGE Framework}

I obtain the following set of log-linearized equilibrium conditions. Hat variables denote percentage deviations of variables from steady state. The consumer Euler equation can be manipulated to obtain an intertemporal "New IS" curve,

$$
\hat{x}_{t}=E_{t}\left[\hat{x}_{t+1}\right]-\frac{s_{c}}{\sigma}\left[\hat{R}_{t}-E_{t}\left[\hat{\pi}_{t+1}\right]-\hat{r} r_{t}^{f}\right]
$$

where $E_{t}\left[\hat{\pi}_{t+1}\right]$ is the expected gross inflation rate, $\hat{x}_{t}$ denotes the output gap, defined as the difference between the distorted and the flexible price - full information

output, $\hat{R}_{t}$ is the nominal interest rate, $\hat{r r}_{t}^{f}$ denotes the flexible price - full information real interest rate and $s_{c}$ is the steady state consumption to output ratio.

Using the optimality conditions of the household, real money demand, $\hat{m}_{t}$, in this economy can be derived as a function of the output gap, exogenous disturbances for technology, $\hat{z}_{t}$, and government expenditures, $\hat{g}_{t}$, and the nominal interest rate,

$$
\hat{m}_{t}=\frac{\sigma}{s_{c} v} \hat{x}_{t}+\frac{\sigma}{s_{c} v \varphi} \hat{z}_{t}-\gamma_{g} \hat{g}_{t}-\frac{1}{v(\bar{R}-1)} \hat{R}_{t}
$$

where $\varphi=\frac{\omega+\sigma s_{c}^{-1}}{1+\omega}, \omega=\frac{\phi}{\alpha}+\frac{1}{\alpha}-1$ and $\gamma_{g}=\frac{\sigma\left(1-s_{c}\right)}{s_{c} v}\left(1-\frac{\sigma s_{c}^{-1}}{\omega+\sigma s_{c}^{-1}}\right)$. Expressing nominal money supply in real terms, real money supply in my economy is given as

$$
\hat{m}_{t}=\hat{m}_{t-1}-\hat{\pi}_{t}+\hat{\zeta}_{t}
$$

where $\hat{\xi}_{t}$ denotes money growth. Solving for the flexible price - full information allocations of the economy yields the flexible price - full information real interest rate which can be expressed as

$$
r \hat{r}_{t}^{f}=\mu_{r g} \hat{g}_{t}+\mu_{r z} \hat{z}_{t}
$$

with $\mu_{r g}=\frac{\sigma\left(\rho_{g}-1\right)}{s_{c}}\left(\frac{\sigma\left(1-s_{c}\right)}{s_{c} \omega+\sigma}+s_{c}-1\right)$ and $\mu_{r z}=\frac{\sigma(1+\omega)\left(\rho_{z}-1\right)}{s_{c} \omega+\sigma}$. 
Finally, I collect the log-linearized exogenous stochastic processes for technology, $\hat{z}_{t}=\rho_{z} \hat{z}_{t-1}+\epsilon_{z, t}$, for money growth, $\hat{\xi}_{t}=\rho_{\xi} \hat{\xi}_{t-1}+\epsilon_{\xi, t}$ and for government expenditures, $\hat{g}_{t}=\rho_{g} \hat{g}_{t-1}+\epsilon_{g, t}$.

\section{A.2 A 2-Year Announced Disinflation}

In order to model a 2-year (8 quarters) announced disinflation we proceed as follows. I replace money growth $\hat{\xi}_{t}$ in the real money supply equation (23) in the log-linearized system of equations by the auxiliary variable $\hat{\xi}_{t}^{a 8}$. Moreover, I make no more use of the exogenous money growth process in the system of equations. Instead, I add the following auxiliary variables to my system of equilibrium equations:

$$
\begin{aligned}
\hat{\xi}_{t}^{a 8} & =\hat{\xi}_{t-1}^{a 7} \\
\hat{\xi}_{t}^{a 7} & =\hat{\xi}_{t-1}^{a 6} \\
& \vdots \\
\hat{\xi}_{t}^{a 1} & =\hat{\xi}_{t-1}^{a 0} \\
\hat{\xi}_{t}^{a 0} & =\rho_{\xi} \hat{\xi}_{t-1}^{a 0}+\epsilon_{\xi, t} .
\end{aligned}
$$

This structure implies that an innovation in say $\hat{\xi}_{t}^{a 0}$ in period $t=0$ is fully observed by the households, sticky price firms and sticky information firms that just had an information update. However, it takes 2 years (8 quarters) until $\hat{\zeta}^{a 8}$ changes in the real money demand equation in the system of equations. Thus, the innovation in $\hat{\xi}_{t}^{a 0}$ in period $t=0$ can be interpreted as an announcement that 2 years later money growth will be changed. Again, I use Uhlig (1999) and my solution procedure described in section 2.7 to solve for the recursive equilibrium law of motion. 


\section{Earlier Working Papers:}

For a complete list of Working Papers published by Sveriges Riksbank, see www.riksbank.se

Evaluating Implied RNDs by some New Confidence Interval Estimation Techniques

by Magnus Andersson and Magnus Lomakka....

Taylor Rules and the Predictability of Interest Rates

by Paul Söderlind, Ulf Söderström and Anders Vredin ......................................................... 2003:147

Inflation, Markups and Monetary Policy

by Magnus Jonsson and Stefan Palmqvist.....

Financial Cycles and Bankruptcies in the Nordic Countries by Jan Hansen........................................ 2003:149

Bayes Estimators of the Cointegration Space by Mattias Villani .................................................. 2003:150

Business Survey Data: Do They Help in Forecasting the Macro Economy?

by Jesper Hansson, Per Jansson and Mårten Löf

The Equilibrium Rate of Unemployment and the Real Exchange Rate:

An Unobserved Components System Approach by Hans Lindblad and Peter Sellin ........................ 2003:152

Monetary Policy Shocks and Business Cycle Fluctuations in a

Small Open Economy: Sweden 1986-2002 by Jesper Lindé

Bank Lending Policy, Credit Scoring and the Survival of Loans by Kasper Roszbach .......................... 2003:154

Internal Ratings Systems, Implied Credit Risk and the Consistency of Banks' Risk

Classification Policies by Tor Jacobson, Jesper Lindé and Kasper Roszbach .................................. 2003:155

Monetary Policy Analysis in a Small Open Economy using Bayesian Cointegrated

Structural VARs by Mattias Villani and Anders Warne

Indicator Accuracy and Monetary Policy: Is Ignorance Bliss? by Kristoffer P. Nimark ........................ 2003:157

Intersectoral Wage Linkages in Sweden by Kent Friberg .......................................................... 2003:158

Do Higher Wages Cause Inflation? by Magnus Jonsson and Stefan Palmqvist ............................. 2004:159

Why Are Long Rates Sensitive to Monetary Policy by Tore Ellingsen and Ulf Söderström .................. 2004:160

The Effects of Permanent Technology Shocks on Labor Productivity

and Hours in the RBC model by Jesper Lindé........................................................................ 2004:161

Credit Risk versus Capital Requirements under Basel II: Are SME Loans and Retail

Credit Really Different? by Tor Jacobson, Jesper Lindé and Kasper Roszbach

Exchange Rate Puzzles: A Tale of Switching Attractors

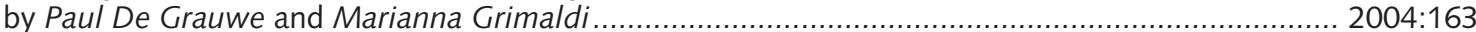

Bubbles and Crashes in a Behavioural Finance Model

by Paul De Grauwe and Marianna Grimaldi.

Multiple-Bank Lending: Diversification and Free-Riding in Monitoring

by Elena Carletti, Vittoria Cerasi and Sonja Daltung.............................................................. 2004:165

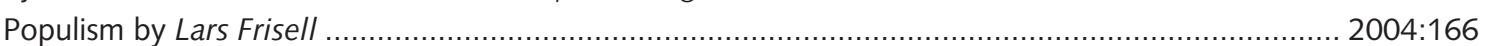

Monetary Policy in an Estimated Open-Economy Model with Imperfect Pass-Through

by Jesper Lindé, Marianne Nessén and Ulf Söderström

Is Firm Interdependence within Industries Important for Portfolio Credit Risk?

by Kenneth Carling, Lars Rönnegård and Kasper Roszbach

$2004: 168$

How Useful are Simple Rules for Monetary Policy? The Swedish Experience

by Claes Berg, Per Jansson and Anders Vredin

The Welfare Cost of Imperfect Competition and Distortionary Taxation

by Magnus Jonsson

A Bayesian Approach to Modelling Graphical Vector Autoregressions

by Jukka Corander and Mattias Villani

Do Prices Reflect Costs? A study of the price- and cost structure of retail payment

services in the Swedish banking sector 2002 by Gabriela Guibourg and Biörn Segendorf

Excess Sensitivity and Volatility of Long Interest Rates: The Role of Limited

Information in Bond Markets by Meredith Beechey.

State Dependent Pricing and Exchange Rate Pass-Through

by Martin Flodén and Fredrik Wilander.

The Multivariate Split Normal Distribution and Asymmetric Principal

Components Analysis by Mattias Villani and Rolf Larsson

Firm-Specific Capital, Nominal Rigidities and the Business Cycle

by David Altig, Lawrence Christiano, Martin Eichenbaum and Jesper Lindé

Estimation of an Adaptive Stock Market Model with Heterogeneous Agents by Henrik Amilon ........ 2005:177

Some Further Evidence on Interest-Rate Smoothing: The Role of Measurement

Errors in the Output Gap by Mikael Apel and Per Jansson...... 
Bayesian Estimation of an Open Economy DSGE Model with Incomplete Pass-Through

by Malin Adolfson, Stefan Laséen, Jesper Lindé and Mattias Villani......

Are Constant Interest Rate Forecasts Modest Interventions? Evidence from

an Estimated Open Economy DSGE Model of the Euro Area by Malin Adolfson,

Stefan Laséen, Jesper Lindé and Mattias Villani

2005:180

Inference in Vector Autoregressive Models with an Informative

Prior on the Steady State by Mattias Villani.

Bank Mergers, Competition and Liquidity by Elena Carletti, Philipp Hartmann

and Giancarlo Spagnolo

Testing Near-Rationality using Detailed Survey Data

by Michael F. Bryan and Stefan Palmqvist.

Exploring Interactions between Real Activity and the Financial Stance

by Tor Jacobson, Jesper Lindé and Kasper Roszbach. 2005:184

Two-Sided Network Effects, Bank Interchange Fees,

and the Allocation of Fixed Costs by Mats A. Bergman 2005:185

Trade Deficits in the Baltic States: How Long Will the Party Last?

by Rudolfs Bems and Kristian Jönsson ....

Real Exchange Rate and Consumption Fluctuations follwing Trade Liberalization

by Kristian Jönsson

Modern Forecasting Models in Action: Improving Macroeconomic Analyses at Central Banks

by Malin Adolfson, Michael K. Andersson, Jesper Lindé, Mattias Villani and Anders Vredin .......... 2005:188

Bayesian Inference of General Linear Restrictions on the Cointegration Space by Mattias Villani ..... 2005:189

Forecasting Performance of an Open Economy Dynamic Stochastic General Equilibrium Model

by Malin Adolfson, Stefan Laséen, Jesper Lindé and Mattias Villani......

2005:190

Forecast Combination and Model Averaging using Predictive Measures

by Jana Eklund and Sune Karlsson

2005:191

Swedish Intervention and the Krona Float, 1993-2002

by Owen F. Humpage and Javiera Ragnartz

A Simultaneous Model of the Swedish Krona, the US Dollar and the Euro

by Hans Lindblad and Peter Sellin.

2006:193

Testing Theories of Job Creation: Does Supply Create Its Own Demand?

by Mikael Carlsson, Stefan Eriksson and Nils Gottfries

Down or Out: Assessing The Welfare Costs of Household Investment Mistakes

by Laurent E. Calvet, John Y. Campbell and Paolo Sodini

2006:195

Efficient Bayesian Inference for Multiple Change-Point and Mixture Innovation Models

by Paolo Giordani and Robert Kohn

Derivation and Estimation of a New Keynesian Phillips Curve in a Small Open Economy

by Karolina Holmberg.

Technology Shocks and the Labour-Input Response: Evidence from Firm-Level Data

by Mikael Carlsson and Jon Smedsaas

Monetary Policy and Staggered Wage Bargaining when Prices are Sticky

by Mikael Carlsson and Andreas Westermark

2006:199

The Swedish External Position and the Krona by Philip R. Lane

$2006: 200$

Price Setting Transactions and the Role of Denominating Currency in FX Markets

by Richard Friberg and Fredrik Wilander....

The geography of asset holdings: Evidence from Sweden

by Nicolas Coeurdacier and Philippe Martin

Evaluating An Estimated New Keynesian Small Open Economy Model

by Malin Adolfson, Stefan Laséen, Jesper Lindé and Mattias Villani.....

2007:203

The Use of Cash and the Size of the Shadow Economy in Sweden

by Gabriela Guibourg and Björn Segendorf

Bank supervision Russian style: Evidence of conflicts between micro- and macro-

prudential concerns by Sophie Claeys and Koen Schoors

2007:205

Optimal Monetary Policy under Downward Nominal Wage Rigidity

by Mikael Carlsson and Andreas Westermark

Financial Structure, Managerial Compensation and Monitoring

by Vittoria Cerasi and Sonja Daltung

Financial Frictions, Investment and Tobin's q by Guido Lorenzoni and Karl Walentin.

2007:208 
Sveriges Riksbank

Visiting address: Brunkebergs torg 11

Mail address: se-103 37 Stockholm

Website: www.riksbank.se

Telephone: +46878700 00, Fax: +468210531

E-mail: registratorn@riksbank.se 